\title{
Laat duizend bloemen bloeien: Tolerantie in en rond organisaties
}

Citation for published version (APA):

van Witteloostuijn, A. (1994). Laat duizend bloemen bloeien: Tolerantie in en rond organisaties. Academic Service, Economie en Bedrijfskunde. https://doi.org/10.26481/spe.19940422aw

Document status and date:

Published: 22/04/1994

DOI:

10.26481/spe.19940422aw

Document Version:

Publisher's PDF, also known as Version of record

\section{Please check the document version of this publication:}

- A submitted manuscript is the version of the article upon submission and before peer-review. There can be important differences between the submitted version and the official published version of record.

People interested in the research are advised to contact the author for the final version of the publication, or visit the DOI to the publisher's website.

- The final author version and the galley proof are versions of the publication after peer review.

- The final published version features the final layout of the paper including the volume, issue and page numbers.

Link to publication

\footnotetext{
General rights rights.

- You may freely distribute the URL identifying the publication in the public portal. please follow below link for the End User Agreement:

www.umlib.nl/taverne-license

Take down policy

If you believe that this document breaches copyright please contact us at:

repository@maastrichtuniversity.nl

providing details and we will investigate your claim.
}

Copyright and moral rights for the publications made accessible in the public portal are retained by the authors and/or other copyright owners and it is a condition of accessing publications that users recognise and abide by the legal requirements associated with these

- Users may download and print one copy of any publication from the public portal for the purpose of private study or research.

- You may not further distribute the material or use it for any profit-making activity or commercial gain

If the publication is distributed under the terms of Article $25 \mathrm{fa}$ of the Dutch Copyright Act, indicated by the "Taverne" license above, 
Laat duizend bloemen bloeien 


\title{
LAAT DUIZEND \\ BLOEMEN BLOEIEN
}

\author{
TOLERANTIE IN \\ EN ROND \\ ORGANISATIES
}

\begin{abstract}
Rede
in verkorte vorm uitgesproken bij de aanvaarding van het ambt van hoogleraar in de bedrijfseconomie, in het bijzonder in de organisatie, aan de Faculteit der Economische Wetenschappen van de Rijksuniversiteit Limburg te Maastricht op vrijdag 22 april 1994

door

Arjen van Witteloostuijn
\end{abstract}




\section{CIP-GEGEVENS KONINKLIJKE BIBLIOTHEEK, DEN HAAG}

Witteloostuijn, A. van

Laat duizend bloemen bloeien : tolerantie in en rond organisaties / A. van Witteloostuijn. - Schoonhoven : Academic Service, Economie en Bedrijfskunde. - Ill. Met lit. opg.

ISBN 90-5261-143-2

NUGI 684

Trefw.: management ; organisaties.

$P=116651776$

Universileitsbibtlothouk

Rijksuniversiteit Limburg

Uitgegeven door: Academic Service, Schoonhoven

Druk: Krips Repro Meppel

ISBN 9052611432

NUGI 684

Copyright (C) 1994 A. van Witteloostuijn

Niets uit deze uitgave mag worden verveelvuldigd en/of openbaar gemaakt door middel van druk, forokopie, microfilm, geluidsband, elektronisch of op welke andere wijze ook en evenmin in een retrieval system worden opgeslagen zonder voorafgaande schriftelijke toestemming van de uitgever.

Hoewel dit boek met veel zorg is samengesteld, aanvaarden schrijver(s) noch uitgever enige aansprakelijkheid voor schade ontstaan door eventuele fouten en/of onvolkomenheden in dit boek. 


\section{Inhoud}

$\begin{array}{ll}\text { Inleiding } & 7\end{array}$

1 Het vermogen tot aanpassing 7

2 Flexertie: flexibiliteit en inertie 9

3 Naar een economische $(r)$ contingentietheorie 12

4 Drie voorbeelden van kwantitatief onderzoek 22

5 Tolerantie en variatie $\quad 35$

6 Besluit $\quad 37$

Dankbetuiging $\quad 41$

$\begin{array}{ll}\text { Literatuurlijst } & 43\end{array}$ 


\section{Inleiding ${ }^{1}$}

Een oratie is een rituele dans; laten we eerlijk zijn. Maar rituele dansen kunnen mooi, spannend en in ieder geval onderhoudend zijn. Ik hoop dat ik in staat blijk deze rede ten minste deze laatste eigenschap mee te geven. In een oratie wordt van de genomineerde hooglemar verwacht dat - in mijn geval - hij een visie op het vak verwoordt. Dat valt niet mee als je - zoals in mijn geval - geen visie hebt. Een oratie wordt geacht begrijpelijk te zijn voor de geïnteresseende leek. Ook dat valt niet mee voor iemand die gewend is indruk te maken via het ordenen van moeilijke woorden en - als het even kan - het gebruik van jargon. Over die interesse zwijg ik het liefst in alle talen. Maar goed, ik moet wel om de eenvoudige reden dat de facultaire reglementen voorschrijven dat het verkrijgen van een B-hoogleraarschap - en dat loont - alleen mogelijk is nadat de betrokkene een inaugurele rede heeft uitgesproken. Laten we daarom maar proberen het beste ervan te maken.

Nog één waarschuwing vooraf. In de universitaire 'Regeling der inaugurele redes' - het zou een gemiste kans zijn geweest als ook hiervoor geen reglementen zouden zijn opgesteld - staat in de inleiding dat "de structuur van de oratie overzichtelijk [dient] te zijn". Dat zal wederom niet meevallen. Ik beloof $\mathrm{u}$ echter dat ik mijn uiterste best zal doen $u$ ten minste enigszins wegwijs te maken in het labyrint dat de organisatiewetenschappen heet. Een troost voor de ware liefhebber: $u$ kunt het later allemaal nog eens rustig nalezen.

\section{Het vermogen tot aanpassing}

Het vermogen tot aanpassing: daarover gaat deze rede. Vivaldi en Nirvana: wie probleemloos heeft kunnen overschakelen van het één

1 Om elk misverstand uit te sluiten: de inhoud van deze oratie heeft niets van doen met de Chinese 'keizer' Mao. Aan Mao wordt de uitspraak toegeschreven dat zijn culturele revolutie honderd bloemen heeft laten bloeien. Om de kans op associaties met deze wrange uitspraak te verkleinen spreek ik van duizend bloemen. 
naar het ander en van beide heeft kunnen genieten, verdient een pluim. Aanpassen is moeilijk. Het thema aanpassing door organisaties', en daarmee ook aanpassing door mensen binnen organisaties, is nieuw noch eenvoudig. Sterker nog: de vraagstelling is misschien zelfs afgezaagd en zeker onoplosbaar. De voortdurende aandacht voor het aanpassingsvermogen van organisaties, en daarmee hun succes of falen, is niet verwonderlijk. Het groeien en krimpen of het komen en gaan van organisaties vormen een boeiend tafereel, dat zich ook in de warme belangstelling van de journalistiek mag verheugen. Niet alleen is elk geval van succes en vooral faling goed voor een forse dosis drama, ook de maatschappelijke consequenties ervan zijn verstrekkend. De Nederlandse voorbeelden uit de afgelopen paar jaar spreken boekdelen: het drietal DAF, Fokker en Philips is illustratief. Het lijkt zelfs wel of de aandacht voor organisatiefalen - en de mogelijke remedies - alleen maar aan het toenemen is nu zelfs vertrouwde giganten als Daimler Benz en IBM zijn gaan wankelen, en ook het Japanse bedrijfsleven niet meer is wat het tot voor kort was.

Het aantal aangedragen oplossingen in de wetenschappelijke literatuur is zolangzamerhand ontelbaar: 'key success factors', 'core capabilities', 'learning organization', 'total quality management', 'lean production', 'business process redesign', et cetera. ${ }^{3}$ Stuk voor stuk benadrukken deze concepten het belang van aanpassing en flexibiliteit. Stuk voor stuk ook is het oude wijn in nieuwe zakken. Ongetwijfeld is weer een groot aantal nieuwe zakken in voorbereiding; de voorraad wijn is immers onuitputtelijk. Het wachten is op de volgende goeroe: de volgende Peter Drucker, Michael Porter of Tom Peters. En laten we wel wezen: managementgoeroe-zijn verdient goed.

2 Hoewel ik mij - naar ik hoop - na deze oratie formeel hoogleraar in de bedrijfseconomie mag noemen, is de benaming organisatie te prefereren boven bedrijf (of onderneming). Eigenlijk is het etiket bedrijfseconomie (of bedrijfskunde) misleidend, omdat veel van de hiermee geassocieerde inzichten en vakgebieden even goed zijn toe te passen in de context van niet-winstorganisaties. Desalniettemin zal ik ook regelmatig refereren aan bedrijven of ondernemingen om (i) variatie in woordgebruik te bevorderen of (ii) het belang van het opereren in een concurrentie-omgeving te benadrukken. Overigens hebben ook veel niet-winstorganisaties, zoals (semi-)overheidsinstellingen, in toenemende mate te kampen met de tucht van de markt. Sterker nog: het is modern (maar misplaatst?) om dergelijke organisaries om te vormen tot en/of te behandelen als bedrijven.

3 Om aan te slaan moet het concept in ieder geval Engelstalig zijn. Vervolgens is het raadzaam om de benaming in Nederlandstalige teksten onvertaald te laten. Dat maakt indruk. 
De vraag is echter hoe het is gesteld met die oude wijn. Is hij nog goed, of is hij misschien zelfs beter geworden? En, om te beginnen: hoe smaakt hij? De eerste druiven waaruit hij is gerijpt, stammen uit het begin van deze eeuw. Na vooroorlogse pioniers als Taylor (1911) en Barnard (1938) is het werk in de jaren zestig met kracht voortgezet en bekend geworden onder de noemer van de contingentietheorie via de bijdragen van bijvoorbeeld Burns \& Stalker (1961), Lawrence \& Lorsch (1967) en Woodward (1965). In de jaren zeventig en tachtig is deze theorie steeds verder verfijnd, vooral met behulp van empirische studies (Pennings, 1993). Maar de centrale vraag is dezelfde gebleven: "welke (interne) organisatiekenmerken sluiten aan bij welke (externe) omstandigheden in de omgeving?" Een voorbeeld: als de omgeving stabiel is en voor weinig verrassingen zorgt, moet de organisatie dan gecentraliseerd of gedecentraliseerd worden ingericht? De algemene vraagstelling in de contingentietheorie heeft alles te maken met een speurtocht naar een voortdurende afstemming ('fit') tussen de externe omgeving enerzijds en de interne organisatie anderzijds. In een dynamische context verwijst deze vraagstelling weer naar het aanpassingsvermogen van organisaties (Miles \& Snow, 1984; en Pennings, 1993). Op deze contingentietheorie kom ik verderop terug. Allereerst is het van belang de fundamentele paradox die de wortel van deze traditie vormt, kort te schetsen.

\section{Intermezzo I}

$U$ vraagt zich inmiddels - of misschien zelfs al sinds lange tijd - af hoe het mogelijk is dat iemand als ik het academische walhalla, het hoogleraarschap, heeft weten te bereiken. $U$ staat daarin niet alleen. Ook ik stel mij regelmatig deze vraag. Een eenvoudig antwoord is: elke organisatie maakt fouten, ook de Faculteit der Economische Wetenschappen van de Rijksuniversiteit Limburg. Het grote probleem is: ik ben eigenlijk nergens werkelijk goed in. Een enkeling denkt misschien nog dat ik een getalenteerd wiskundig econoom ben. Niets is minder waar: zelfs de kettingregel heb ik niet paraat. Dat ik econometrisch van toet(s)en noch blazen weet, is een publiek geheim. Wat blijft dan over? Creatief plak- en knipwerk. Een concept hier, een theorie daar en: plakken maar! Zonder de steun van wel getalenteerde collega's was het tobben geblazen. In dit verband zal het $u$ direct opvallen dat de navolgende referenties naar eigen werk bijna altijd co-produkties met collega's betreffen.

\section{Flexertie: flexibiliteit en inertie}

Zoals gezegd, een - en misschien zelfs de - cruciale vraag tiı de organisatiewetenschappen is waarom de ene organisatie het beter doet dan de andere. De vele antwoorden die op deze vraag inmiddels zijn 
gegeven, schilderen een paradox: om te groeien - of zelfs om te overleven - moet een organisatie gelijktijdig flexibel en inert zijn. Een paradox is een schijnbare tegenstelling, maar wat maakt dit fundamentele dilemma tot een schijnbaar in plaats van werkelijk conflict? Om hierin inzicht te krijgen is het nuttig allereerst de twee extreme posities kort te kenschetsen: het strategisch management enerzijds, dat grosso modo de mogelijkheden tot en het belang van flexibiliteit benadrukt, en de organisatie-ecologie anderzijds, dat berust op de centrale gedachtengang dat organisaties per saldo inert zijn en zelfs moeten zijn.

Het stmategisch management mag zich, ondanks (of dankzij?) zijn jeugdige leeftijd, in een grote populariteit verheugen. Het antwoord op de vraag wat strategisch management eigenlijk is, biedt voldoende stof om een afzonderlijk oratie mee te vullen (Mintzberg, 1987). Voorop staat het begrip strategie: een strategie geeft richting aan de activiteiten van een organisatie. Verder is het hier voldoende te beseffen dat alle leerboeken in het strategisch management - een enkele uitzondering daargelaten - stoelen op de gedachte dat na een systematische analyse van de externe kansen en bedreigingen aan de ene kant en de interne sterkten en zwakten aan de andere kant een organisatie haar strategie in de gewenste richting moet en kan aanpassen (Johnson \& Scholes, 1993). ${ }^{4}$ Kortom: organisatorische flexibiliteit is bijna een sine-qua-non voor de gebruikmaking van de inzichten uit het strategisch management. Is een organisatie te groot, dan is een krimpstrategie aangewezen. Is de produktiecapaciteit te klein, dan moet aan uitbreiding van produktiefaciliteiten worden gewerkt. Is een markt niet langer rendabel, dan is het tijd om uit te treden. Is de functionele structuur niet langer geschikt, dan moet worden overgestapt op een divisie-indeling. Et cetera.

Vanuit het perspectief van het strategisch management betekent flexibiliteit dat zonder veel kosten van koers kan worden veranderd. Een flexibele strategie laat toe dat $a$ in plaats van $b$ wordt uitgevoerd, of dat zonder veel moeite (in tijd en geld) van $a$ op $b$ kan worden overgegaan. In veel gevallen is een dergelijke flexibiliteit echter af te

4 Een illustratieve uitzondering is het leerboek van Stacey (1993). Het is gebruikelijk een onderscheid te maken tussen strategie-inhoud en strategieproces. Grosso modo kan worden gezegd dat vooral de literatuur inzake de strategie-inhoud - zoals de bekende boeken van Porter (1980 \& 1985) - het belang van en de mogelijkheden tot flexibiliteit benadrukt, terwijl in de geschriften over het strategieproces - met als sprekend voorbeeld het logisch incrementalisme van Quinn (1978 \& 1980) - vaak aandacht wordt geschonken aan de voor- en nadelen van inertie. 
raden. Alleen via het aangaan van verplichtingen ('commitments') kan een strategie geloofwaardig worden gemaakt (Ghemawat, 1991). Zonder verplichting - en daarmee inertie - is een strategie vrijblijvend, en daarmee niet meer dan een loos dreigement (Schelling, 1960). Met andere woorden: strategische flexibiliteit leidt tot ongeloofwaardigheid. Neem het volgende voorbeeld. Zonder moeite kan een zittende onderneming potentiële concurrenten dreigen met het installeren van additionele produktiecapaciteit, die vervolgens na toetreding zou kunnen worden ingezet om via een prijzenoorlog toetreders weer tot uittreding te dwingen. Dit dreigement alleen is echter onvoldoende. De beoogde toetredingsbelemmerende strategie is pas geloofwaardig indien de zittende onderneming reeds over overcapaciteit beschikt. In het algemeen geldt dat de geloofwaardigheid van concurrentiestrategieën gebaat is bij het uitvoeren van onomkeerbare investeringen (Van Witteloostuijn, 1993). Via dergelijke onomkeerbare investeringen geeft een onderneming aan dat zij zich heeft gebonden aan (of verplicht tot) de uitvoering van specifieke strategieën.

Aanhangers van de organisatie-ecologie (Hannan \& Freeman, 1989) gaan zelfs nog een stap verder: om te overleven moeten ondernemingen inert zijn. De organisatie-ecologie (ook wel 'populatie-ecologie' genoemd) is een vrij jonge loot aan de stam van de organisatiesociologie die tegengif produceert dat de optimistische visie van het strategisch management tracht te relativeren. In hun baanbrekende artikel uit 1977 poneren Hannan \& Freeman de controversiële stelling dat organisatie-inertie niet alleen de overlevingskansen van een organisatie verhoogt, maar dat deze inertie zelfs het resultaat is van externe selectieprocessen. ${ }^{5}$ In de jaren daarna is deze gedachtengang verder theoretisch verfijnd en empirisch getoetst (Hannan \& Freeman, 1989; en Hannan \& Carroll, 1992). In vogelvlucht verloopt de redenering als volgt. In de eerste plaats dienen organisaties betrouwbaar te zijn: organisaties zijn betrouwbare leveranciers (bijvoorbeeld in termen van kwaliteit en levertijd) omdat zij routinematige gedragspatronen (of blauwdrukken) hebben ontwikkeld die de activiteiten sturen. In de tweede plaats beschikken organisaties over de belangrijke eigenschap beter verantwoording te kunnen afleggen voor hun daden: investeerders, afnemers, leveranciers en dergelijke verwachten redelijke en consistente berichtgevingen inzake de wijze waarop de organisaties zich gedragen. In de derde plaats vergt het

5 Strikt genomen spreken organisatie-ecologen van relatieve of 'structurele' inertie (Hannan \& Freeman, 1984). Dat wil zeggen: organisaties zijn inert in verhouding tot het tempo waarin zich veranderingen in de omgeving voordoen. Voor de eenvoud ga ik hier aan deze subtiliteit voorbij. 
waarborgen van betrouwbaarheid en aanspreekbaarheid een sterke mate van reproduceerbaarheid van organisatiestructuren: de routines, regels en procedures die betrouwbaarheid en aanspreekbaarheid garanderen, moeten gisteren, vandaag en morgen werkzaam zijn. Deze reproduceerbaarheid impliceert inertie: inertie is dus een gevolg van in plaats van een conditie voor selectie. In dit verband is het interessant te vermelden dat falende ondernemingen vaak gedurende een aantal jaren voor de datum van uittreding een overmaat aan flexibiliteit hebben ten toon gespreid. Juist hyperactiviteit is de voorbode van het uiteindelijke faillissement geweest (Hambrick \& D'Aveni, 1988).

De tegenstelling tussen flexibiliteit en inertie is echter oplosbaar. Zoals gezegd, is een strategie pas geloofwaardig als zij gepaard gaat met een verplichting. Waar het om gaat is dat strategieën aan kracht winnen indien zij leiden tot onomkeerbare investeringen. Een onomkeerbare investering (dat wil zeggen: het inbouwen van inertie) in flexibele produktiesystemen kan een concurrentievoordeel genereren. Het gevaar van onomkeerbaarheid is natuurlijk dat de 'optimaliteit' van de geassocieerde investering niet tijdloos is. Wat nu een voordeel is, kan later tot een nadeel worden. Met andere woorden: strategisch management impliceert een voortdurende keuze voor en evaluatie van verplichtingen (inerties), waarbij de portefeuille van de verplichtingen zorgurldig moet worden samengesteld en, desnoods, aangepast. De flexibiliteit schuilt in deze aanpassingen van de portefeuille van inerties. Het gaat niet om flexibiliteit of inertie, maar om een combinatie van beide: flexertie. Het is dit voortdurende dilemma, flexibiliteit versus inertie, dat het centrale probleem vormt van het strategisch management. Met andere woorden: een strategisch manager moet flexibel zijn door voortdurend de keuze van inerties te (her)overwegen. De paradox is compleet: in inertie schuilt het duurzame en het unieke, en daarmee een potentieel concurrentievoordeel. In die zin kunnen investeringen in flexibele produktiesystemen een strategische verplichting impliceren. Maar strategische flexibiliteit is een teken van zwakte.

\section{Naar een economische(r) contingentietheorie}

Mijn werkplek is de Maastrichtse economische faculteit. Maar hebben de economische wetenschappen eigenlijk wel wat te zeggen over het functioneren van organisaties in het algemeen en het hiervoor beschreven dilemma tussen flexibiliteit en inertie in het bijzonder? De organisatiewetenschappen zijn van oudsher multidisciplinair. Vandaar ook het 
meervoud. De organisatiepsychologie en -sociologie hebben sinds jaar en dag een gevestigde positie binnen de Faculteiten der Sociale Wetenschappen in binnen- en buitenland. Maar bestaat de - of in ieder geval een - organisatie-economie eigenlijk wel? Het antwoord op deze vraag is een volmondig "ja". De twee recente leerboeken van Douma \& Schreuder (1991) en Milgrom \& Roberts (1992) illustreren overduidelijk dat de organisatie-economie vaste voet aan de grond begint te krijgen in binnen- en buitenlandse curricula. Ruwweg kan een tweetal groepen van economische organisatietheorieën worden onderscheiden: varianten van de agentschapstheorie aan de ene kant, en verschijningsvormen van de industriële organisatie aan de andere kant. Hierbij richt de agentschapstheorie zich op het interne en concentreert de industriële organisatie zich op het externe functioneren van organisaties. ${ }^{6}$

De agentschapstheorie bestaat uit een verzameling van modellen en studies die de relatie tussen een leidinggevende (of eigenaar) - de zogenaamde principaal - en ondergeschikten - agenten genoemd - tot onderwerp van analyse hebben genomen. Hiermee houdt deze economische theorie zich bezig met het interne functioneren van organisaties. De economische theorie van het interne functioneren van organisaties is vrij jong. Tot in de jaren zeventig zijn de bijdragen aan deze tak van de economische wetenschappen slechts spaarzaam geweest, maar inmiddels kan hier worden gesproken van hoogconjunctuur (Holmstrom \& Tirole, 1989; en Milgrom \& Roberts, 1992). Hierbij hebben de klassieke bijdragen van Arrow (1963) en Alchian \& Demsetz (1972) de toon gezet door de rol van (asymmetrische) informatie respectievelijk (incomplete) contracten central te stellen. In de agentschapstheorie draait het uiteindelijk om prikkelsystemen (Jensen \& Meckling, 1976): hoe kan de principaal ervoor zorgen dat de agenten het door hem gewenste gedrag vertonen? Hierbij kunnen onder meer specifieke structuren worden ontworpen - hoe moet bijvoorbeeld het besluitvormingsproces worden ingericht (Sah \& Stiglitz, 1988)? - en/of bepaalde beloningssystemen worden ingevoerd - in welke mate moet bijvoorbeeld worden gewerkt met prestatiebeloningen (Jensen \& Murphy, 1990)?

In het licht van het flexibiliteit-inertiedebat is het relevant om te constateren dat de inzichten en aanbevelingen die voortvloeien uit de agentschapstheorie, bijna altijd (of altijd?) de introductie van inerties

6 Een derde economische organisatiecheorie - de transactiekosteneconomie (Williamson, 1989) - beweegt zich op het snijvlak tussen de externe en de interne organisatie. Kortheidshalve laat ik deze variant hier rusten. 
inhouden. In de vorm van structuren (hiërarchieën) en/of beloningen (bonussen) worden organisatieparticipanten - de agenten - geconfronteerd met van bovenaf opgelegde restricties - door de principaal - die hun bewegingsvrijheid inperken of bijsturen. ${ }^{7}$ Een voorbeeld is een bonussysteem waarbij agenten hogere beloningen ontvangen naarmate zij meer verkopen (in paragraaf 4 kom ik hierop terug). Dit beloningssysteem is vanuit het perspectief van de agent een restrictie die hem ertoe kan brengen zijn gedrag in een specifieke richting bij te sturen.

De industriële organisatie is de economische theorie van marktwerking, en daarmee van het externe functioneren van organisaties. Vanaf de begintijd van de economische wetenschappen - denk maar aan de onzichtbare hand van Adam Smith (1776) ${ }^{8}$ - heeft de bestudering van de werking van markten en concurrentieprocessen een centrale plaats ingenomen.' Tot in de jaren zeventig van deze eeuw is de industriële organisatie gedomineerd geweest door het structuur-gedrag-prestatieraamwerk (Scherer \& Ross, 1990), waarbij de nadruk werd gelegd op empirisch onderzoek naar het wel en wee van bedrijfstakken. In de laatste twee decennia heeft de moderne industriële organisatie (Tirole, 1988) de dominante plaats van het structuur-gedrag-prestatieraamwerk overgenomen. Deze moderne variant wordt gekenmerkt door een grote aandacht voor theorievorming met behulp van speltheoretische modellen (Fisher, 1989). Inmiddels beweegt de pendule weer in de richting van meer empirisch onderzoek (Shapiro, 1989), waarbij pogingen worden ondernomen om de speltheoretische voorspellingen te toetsen aan de concurrentiepraktijk in bedrijfstakken (Sutton, 1991). De centrale dubbelvrag in de theoretische en empirische industriële organisatie is hoe het verloop en de uitkomst van concurrentieprocessen

7 De agentschapstheorie - met haar nadruk op de rol van prikkelsystemen - vertoont overigens opvallende gelijkenissen met varianten van de traditionele organisatiesociologie. Een illustratief voorbeeld van deze laatste benadering is Lammers (1993).

8 De geschiedkundig liefhebber kan aan de hand van bijvoorbeeld Schumpeter (1954) overigens terug gaan tot de klassieke oudheid.

9 In dit verband is het illustratief dat in de moderne industriële organisatie de twee basisvormen van concurrentie - Bertrand of prijsconcurrentie respectievelijk Cournot of hoeveelheidsconcurrentie - die de fundamentele bouwstenen vormen van vrijwel alle moderne speltheoretische modellen van marktwerking, zijn genoemd naar twee pioniers uit de vorige eeuw [Cournot (1838) en de verlate reactie daarop van Bertrand (1883)]. 
kunnen worden verklaard, en wat dergelijke processen betekenen voor de maatschappelijke welvaart (Schmalensee \& Willig, 1989).

De moderne variant heeft één inzicht toegevoegd aan de stand van kennis binnen de industriële organisatie dat in de context van het thema van vandaag - het flexibiliteit-inertiedilemma - niet onvermeld mag blijven: strategie als verplichting (Dixit, 1982). Ik heb hierbij in de vorige paragraaf al even kort stilgestaan. Ook aan het belang van flexibiliteit wordt in de industriële organisatie niet voorbijgegaan. Laat ik bij wijze van illustratie kort twee voorbeelden aanstippen. Dixit (1992) laat zien dat in het licht van onzekerheid over vraagontwikkelingen in de toekomst een winstmaximaliserende onderneming gebaat is bij het uitstellen van onomkeerbare investeringen in produktiecapaciteit. Met andere woorden: wachten met investeren kan optimaal zijn omdat de onderneming daarmee haar flexibiliteit behoudr, zodat het mogelijk is om later direct op onverwachte gebeurtenissen te reageren. Spencer \& Brander (1992) werken deze gedachtengang verder uit aan de hand van een drietal specifieke oligopoliemodellen. Het blijkt mogelijk te zijn om, gegeven de aard en intensiteit van de onzekerheid, een 'optimale graad van inertie' te bepalen. Ik kom hierop terug in paragraaf 4 .

Het moge duidelijk zijn: ook binnen de organisatie-economie heeft het flexibiliteit-inertiedilemma veel aandacht gekregen. Het is mijn overtuiging dat deze economische inzichten de traditionele contingentietheorie kunnen versterken. ${ }^{10}$ Ook vanuit een economische invalshoek kan de vraag worden beantwoord onder welke omstandigheden specifieke combinaties van externe en interne organisatiekenmerken tot de beste prestaties leiden. Of, vanuit een dynamisch perspectief: ook de organisatie-economie biedt inzichten inzake de noodzaak en het vermogen tot aanpassing van organisaties. In paragraaf 4 hoop ik $u$ aan de hand van een drietal concrete voorbeelden van onderzoek te overtuigen van de nuttige bijdrage die de organisatie-economie kan leveren.

10 Het accent op de economische inbreng komt overeen met wat mijn voorganger Schreuder (1985) 'economieën bedrijven' noemt. Het is een poging te laveren tussen de Scylla van een restrictieve definitie van de bedrijfseconomie en de Charybdis van de niet-restrictieve variant. De implicatie is dat vanuit een in eerste instantie economische invalshoek zonodig niet-economische perspectieven worden geïntroduceerd, afhankelijk van de specifieke probleemstelling van een onderzoek. 
Is het eigenlijk wel gerechtvaardigd om te spreken van organisatiewetenschappen? In alle eerlijkheid: het vakgebied lijkt in zijn vele gedaanten meer op een speculatieve ambacht. Veel wordt beweerd, weinig wordt bewezen. Het is tekenend dat de Economische Faculteit alhier het zekere voor het onzekere heeft genomen door niet te kiezen: de leeropdracht is organisatie; kaal, zonder de toevoeging 'wetenschappen' of 'kunde'. Ook in het curriculum is deze ambiguilteit te herkennen. Zonder schroom worden vakken als economische organisatietheorie en personeelsmanagement naast elkaar aangeboden. Sommige vakgenoten verdienen hun brood met het verkondigen van de postmoderne theorie van organisaties - wat dat ook moge zijn - terwijl anderen zich alleen bezighouden met een variant van de toegepaste econometrie. Deze pluriformiteit is verwarrend, maar ook uitdagend. In tabel 1 is een poging ondernomen de theoretische pluriformiteit binnen het vakgebied enigszins te structureren. ${ }^{11}$

De indeling is gebaseerd op een tweetal dimensies: (i) het niveau van aggregatie ${ }^{12}$; en (ii) het disciplinaire perspectief ${ }^{13}$. Aan de ene kant kan het

$"$ Twee andere voorbeelden van pogingen - zij het langs andere wegen om (een deel van) het theoretische veld van de organisatiewetenschappen nader te structureren zijn Pfeffer (1982: tabel 1.1 op bladzijde 13) en Douma \& Schreuder (1991: figuur 10.4 op bladzijde 175).

12 Een belangrijk probleem bij het onderscheiden van niveaus van aggregatie is het definiëren van twee cruciale begrippen: organisatie en omgeving. De definitie van beide begrippen is helaas (onvermijdelijk) omgeven door grote ambiguitteit. Twee voorbeelden kunnen dit illustreren. Binnen de industriële organisatie en het strategisch management schittert een precieze definitie van de markt (of de bedrijfstak) door afwezigheid. Het gebruik van kruiselingse prijselasticiteiten (Stigler, 1955) of meervoudige vraag-en aanbodcriteria (Abell, 1980 ) is niet probleemloos, en in elk geval arbitrair. Sterker nog: voor een onderneming is marktafbakening een essentiële strategische beslissing die een onvervreemdbaar onderdeel vormt van de ondernemingsstrategie (die zich richt op de vraag waar, dat wil zeggen: in welke markten, te concurreren). Een vergelijkbaar dilemma speelt binnen de theorie van interne organisatie. Waar houdt de organisatie op te bestaan en begint de omgeving een eigen leven te leiden (Morgan, 1986)? In de praktijk van het theoretisch onderzoek worden deze definitievraagstukken daarom in het algemeen onbesproken gelaten. In empirische studies worden veelal pragmatische criteria gehanteerd die overeen komen met statistische classificatieschema's.

13 In oraties aan de Limburgse economische faculteit is het goed gebruik om aan te geven welke integratiemogelijkheden bestaan tussen deeldisciplines van de economische wetenschappen. In dit verband wijzen bijvoorbeeld van de Poel (1988), Wolff (1989), Dietz (1990) en Kasper (1990) op relaties tussen hun bedrijfseconomische deelgebieden (respectievelijk berichtgeving, financiering, informatie en marketing) en andere subdisciplines. Kruisverbanden met het 
het niveau van aggregatie variëren van 'macro-macro' - de maatschappij als geheel - tot 'micro-micro' - de organisatieparticipant als individu. Aan de andere kant wordt veelvuldig uit drie disciplines geput: economie, psychologie en sociologie. De classificatie in tabel 1 is grofmazig. Binnen bijvoorbeeld de economische invalshoek - zoals ik hierboven enigszins heb proberen aan te geven - bestaat een groot aantal deeltheorieën. Bij wijze van illustratie bevat tabel 2 een fijnmazige indeling met specifieke benaderingen binnen de drie moederdisciplines.

Tabel 1: Grofmazige classificatie van theorieën in de organisatiewetenschappen

\begin{tabular}{|c|c|c|c|}
\hline \multirow{2}{*}{$\begin{array}{c}\text { NIVEAU } \\
\text { VAN } \\
\text { AGGREGATIE }\end{array}$} & \multicolumn{3}{|c|}{ DISCIPLINAIR PERSPECTIEF } \\
\hline & Economie & Psychologie & Sociologie \\
\hline Maatschappij & Macro-economie & Macropsychologie & Macrosociologie \\
\hline $\begin{array}{l}\text { Meervoudige } \\
\text { bedrijfstakken } \\
\end{array}$ & \multirow{2}{*}{$\begin{array}{l}\text { Industriële } \\
\text { organisatie } \\
\text { en strategisch } \\
\text { management }\end{array}$} & - & \multirow{2}{*}{$\begin{array}{l}\text { Organisatie- (of } \\
\text { meso)sociologie }\end{array}$} \\
\hline $\begin{array}{l}\text { Enkelvoudige } \\
\text { bedrijfstak }\end{array}$ & & Mesopsychologie & \\
\hline Organisatie & \multirow{4}{*}{$\begin{array}{l}\text { Economische } \\
\text { theorie van } \\
\text { interne } \\
\text { organisatie }\end{array}$} & \multirow{4}{*}{$\begin{array}{l}\begin{array}{l}\text { Strategisch } \\
\text { management }\end{array} \\
\text { Organisatiegedrag }\end{array}$} & \multirow{3}{*}{$\begin{array}{l}\text { Organisatie- } \\
\text { structuur }\end{array}$} \\
\hline Organisatie- & & & \\
\hline & & & \\
\hline $\begin{array}{l}\text { Organisatie- } \\
\text { participant }\end{array}$ & & & - \\
\hline
\end{tabular}

vakgebied organisatie zijn onder meer terug te vinden via gezamenlijke aandacht voor economische organisatietheorieën (van de Poel, 1988), de afweging tussen informatie- en organisatiegraad (Dietz, 1990) en concurrentieanalyse (Kasper, 1990). Gedicteerd door ruimtegebrek wordt in deze oratie slechts impliciet en zijdelings ingegaan op de mogelijkheden tot intrabedrijfseconomie-integratie'. 
Tabel 2: Fijnmazige classificatie van theorieen in de organisatie. wetenschappen

\begin{tabular}{|c|c|c|c|}
\hline \multirow{2}{*}{$\begin{array}{c}\text { NIVEAU } \\
\text { VAN } \\
\text { AGGREGATIE }\end{array}$} & \multicolumn{3}{|c|}{ DISCIPLINAIR PERSPECTIEF } \\
\hline & Economie & Psychologie & Sociologie \\
\hline Maatschappij & $\begin{array}{l}\text { - Publieke } \\
\text { economie } \\
\text { - Internationale } \\
\text { economie }\end{array}$ & $\begin{array}{ll}\text { - } & \text { Nationale } \\
\text { attitude- en } \\
\text { perceptie- } \\
\text { studies } \\
\text { - Nationale } \\
\text { cultuurstudies } \\
\end{array}$ & $\begin{array}{l}\text { - Maatschap- } \\
\text { pelijke } \\
\text { inbedding- } \\
\text { theorie } \\
\text { - Institutionele } \\
\text { theorie } \\
\text { - Bedrijfs- } \\
\text { systeem- } \\
\text { studies }\end{array}$ \\
\hline $\begin{array}{l}\text { Meervoudige } \\
\text { bedrijfstakken }\end{array}$ & $\begin{array}{l}\text { Multimarkt- } \\
\text { concurrentie- } \\
\text { theorie } \\
\text { Onder- } \\
\text { nemings- } \\
\text { strategie- } \\
\text { theorie }\end{array}$ & - & $\begin{array}{l}\text { Meervoudige } \\
\text { populatie- } \\
\text { ecologie } \\
\text { Theorie van } \\
\text { middelen- } \\
\text { afhankelijk- } \\
\text { heden } \\
\end{array}$ \\
\hline $\begin{array}{l}\text { Enkelvoudige } \\
\text { bedrijfstak }\end{array}$ & $\begin{array}{l}\text { Theorie van } \\
\text { geïsoleerde } \\
\text { markt- } \\
\text { concurrentie } \\
\text { Concurrentie- } \\
\text { strategie- } \\
\text { theorie }\end{array}$ & $\begin{array}{l}\text { Bedrijfstak- } \\
\text { cultuurstudies }\end{array}$ & $\begin{array}{l}\text { Enkelvoudige } \\
\text { populatie- } \\
\text { ecologie }\end{array}$ \\
\hline Organisatie & $\begin{array}{l}\text { Micro-econo- } \\
\text { mische theorie } \\
\text { van het bedrijf } \\
\text { Transactie- } \\
\text { kostentheorie }\end{array}$ & $\begin{array}{l}\text { Organisatie- } \\
\text { cultuurstudies } \\
\text { - Strategie- } \\
\text { processtudies }\end{array}$ & $\begin{array}{l}\text { - Contingentie- } \\
\text { theorie }\end{array}$ \\
\hline $\begin{array}{l}\text { Organisatie- } \\
\text { groep }\end{array}$ & $\begin{array}{l}\text { Agentschaps- } \\
\text { theorie } \\
\text { Gedrags- } \\
\text { theorie van } \\
\text { organisaties }\end{array}$ & $\begin{array}{l}\text { Sociale psy- } \\
\text { chologie van } \\
\text { organiseren } \\
\text { Topmanage- } \\
\text { mentteam- } \\
\text { studies } \\
\end{array}$ & $\begin{array}{l}\text { Contingentie- } \\
\text { theorie }\end{array}$ \\
\hline $\begin{array}{l}\text { Organisatie- } \\
\text { participant }\end{array}$ & $\begin{array}{l}\text { Gedrags- } \\
\text { theorie van } \\
\text { organisaties } \\
\text { Micro- } \\
\text { economische } \\
\text { theorie van } \\
\text { besluitvor- } \\
\text { ming }\end{array}$ & $\begin{array}{l}\text { Motivatie- } \\
\text { theorieën } \\
\text { - Leiderschap- } \\
\text { studies }\end{array}$ & - \\
\hline
\end{tabular}


Deze opsomming van deeltheorieën is natuurlijk alles behalve - kan dat misschien zelfs niet zijn - uitputtend. ${ }^{14}$ Verder moet nog worden opgemerkt dat veel theorieën zelf multidisciplinair zijn en/of twee of meer aggregatieniveaus afdekken. De gedragstheorie van organisaties (Cyert \& March, 1963) is bijvoorbeeld economisch en psychologisch, en heeft betrekking op het niveau van de organisatie, de organisatiegroep en de organisatieparticipant. In het algemeen kan echter zonder veel overdrijving worden gesteld dat deeltheorieën binnen de organisatiewetenschappen vooral de nadruk leggen op één van de aggregatieniveaus en disciplinaire perspectieven.

Met gebruikmaking van de - althans in Nederland - traditionele tweedeling van het vakgebied in externe en interne organisatie kan de classificatie in tabel 1 en 2 worden samengevat met de zes groepen van theorieën uit tabel 3.

Tabel 3: Zes groepen van theorieën binnen de organisatiewetenschappen

\begin{tabular}{|c|c|c|c|}
\hline \multirow{2}{*}{$\begin{array}{c}\text { NIVEAU } \\
\text { VAN } \\
\text { AGGREGATIE } \\
\end{array}$} & \multicolumn{3}{|c|}{ DISCIPLINAIR PERSPECTIEF } \\
\hline & Economie & Psychologie & Sociologie \\
\hline $\begin{array}{l}\text { Inter- } \\
\text { organisationeel } \\
\text { (maatschappij, } \\
\text { meervoudige } \\
\text { bedrijfstakken } \\
\text { en/of enkelvou- } \\
\text { dige bedrijfstak) }\end{array}$ & $\begin{array}{l}\text { Inter- } \\
\text { organisationele } \\
\text { economie }\end{array}$ & $\begin{array}{l}\text { Inter- } \\
\text { organisationele } \\
\text { psychologie }\end{array}$ & $\begin{array}{l}\text { Inter- } \\
\text { organisationele } \\
\text { sociologie }\end{array}$ \\
\hline $\begin{array}{l}\text { Intra- } \\
\text { organisationeel } \\
\text { (organisatie, } \\
\text { organisatie- } \\
\text { groep en/of } \\
\text { organisatie- } \\
\text { participant) }\end{array}$ & $\begin{array}{l}\text { Intra- } \\
\text { organisationele } \\
\text { economie }\end{array}$ & $\begin{array}{l}\text { Intra- } \\
\text { organisationele } \\
\text { psychologie }\end{array}$ & $\begin{array}{l}\text { Intra- } \\
\text { organisationele } \\
\text { sociologie }\end{array}$ \\
\hline
\end{tabular}

14 Twee voorbeelden die de onvolledigheid van de opsommingen illustreren, zijn de evolutionaire economie en het internationaal management. De evolutionaire economie is een mengeling van de mesotheorie van concurrentie in de industriële organisatie en de micronotie van bevrediging uit de gedragstheorie van organisaties. Internationaal management isde verzamelnaam van de studies binnen de organisatiewetenschappen die zich richten op internationaal opererende ondernemingen. De oraties van de collega's Soete (1987) en Hagedoorn (1993) handelen over de evolutionaire economie respectievelijk het internationaal management. 
Hierbij vallen de theorieën in de bovenste helft van de tabel onder de noemer 'externe organisatie', en zijn de verzamelingen van theorieën in de onderste helft onderdeel van de 'interne organisatie'. De externe organisatie richt zich vooral op de gedragingen van groepen organisaties in hun onderlinge samenhang (inter-organisationele theorieën), terwijl de interne organisatie met name betrekking heeft op het gedrag binnen en van individuele organisaties (intra-organisationele theorievorming). Het strategisch management opereert op het snijvlak tussen de externe en interne organisatie door de aandacht te vestigen op de noodzakelijke afstemming tussen de externe en interne organisatie. Het is dan ook geen wonder dat juist hier het flexibiliteit-inertiedilemma zich in volle hevigheid voordoet.

Het is misschien nuttig om de zes resulterende deelgebieden binnen de organisatiewetenschappen kort te karakteriseren. Dan weet $\mathrm{u}$ ten minste welke - utopische - leeropdracht ik geacht wordt te vervullen. Ook hier geldt weer dat volledigheid onhaalbaar is.

1. Inter-organisationele economie. Het leeuwedeel van de economische theorievorming richt zich van oudsher op de wereld buiten organisaties. In dit verband is de (micro-)economische standaardveronderstelling dat ondernemingen opereren als entiteiten die een eenduidige doelstelling - meestal winst - nastreven, illustratief. De harde kern van de economische studie van inter-organisationele concurrentie is de industriële organisatie, met name in de vorm van het klassieke structuur-gedrag-prestatieraamwerk (Scherer \& Ross, 1990) en de moderne speltheoretische modellen (Tirole, 1988). Het eerstgenoemde raamwerk heeft Porter (1980) geïnspireerd bij (tot?) de ontwikkeling van zijn vijf-krachtenmodel als het ijkpunt voor een concurrentieanalyse in de context van strategieformulering.

2. Intra-organisationele economie. Een beperkt aantal economische theorieën heeft het interne functioneren van organisaties tot object van studie verheven. Hoewel Coase een aantal aspecten van de interne organisatie via (veeleer dan van) bedrijven reeds in de jaren dertig (1937) heeft geanalyseerd, waarmee hij het fundament legde voor de verkrijging van Nobelprijs van bijna zestig jaar later, heeft de intraorganisationele economie toch vooral in de afgelopen twintig jaar momentum gekregen met als boegbeeld de agentschapstheorie. De recente leerboeken van Douma \& Schreuder (1991) en Milgrom \& Roberts (1992) bieden een introductie tot de huidige stand van kennis.

3. Inter-organisationele psychologie. Vanwege haar object van studie het gedrag en de cognitie van individuele mensen - bestaat binnen de psychologie slechts bij hoge uitzondering aandacht voor bedrijfstakken of de maatschappij als geheel. In de context van vooral de economische psychologie is echter onderzoek verricht naar fenomenen die verband houden met inter-organisationeel gedrag. Voorbeelden van dergelijke onderzoek houden zich bezig met ondernemerschap, koopgedrag, spaarbehoeften en belastingontduiking (Lea, Tarpy \& Webley, 1987). Daarnaast kan de studie naar bedrijfstak- en nationale culturen (Gordon, 1991; en Hofstede, 1991) tot de inter-organisationele psychologie worden gerekend. 
4. Intra-organisationele psychologie. Het gedrag van (groepen van) organisatieparticipanten is het centrale thema in een omvangrijke specialisatie binnen de psychologische discipline: arbeids- en organisatiepsychologie. In het kader van dit deelterrein binnen de psychologie is een groot aantal specifieke onderwerpen onder de loep genomen. Een bekende - uit de Angelsaksische wereld afkomstige - verzamelnaam voor deze inter-organisationele psychologie is organisatiegedrag ('organizational behavior'). De onderwerpen variëren van motivatie en perceptie tot conflict en leiderschap (Robbins, 1993), waarbij zeker ook de bestudering hiervan in de context van het functioneren van topmanagementteams aandacht krijgt.

5. Inter-organisationele sociologie. In zekere zijn is de sociologie - door haar concentratie op het geaggregeerde functioneren van menselijke systemen - het spiegelbeeld van de psychologie. Het deelterrein van de inter-organisationele sociologie heeft een groot aantal theorieën gegenereerd. Ruwweg kunnen hierbij twee typen theorieën worden onderscheiden in termen van het primaire niveau van aggregatie: (i) maatschappelijke of macrotheorieën en (ii) populatie- of mesovarianten. Het eerste type richt zich op de maatschappelijke inbedding van organisaties in het algemeen (Pfeffer \& Salancik, 1978), en het tweede op (enkel- of meervoudige) bedrijfstakomgevingen in het bijzonder (Hannan \& Freeman, 1989).

6. Intra-organisationele sociologie. Een organisatie kan worden beschouwd als een microsamenleving (Lammers, 1993). Mogelijk is dit de reden waarom de sociologie zich ook heeft bezig gehouden met de interne organisatie. Het 'pièce de resistance' van de intra-organisationele sociologie is de contingentietheorie. Deze theorie beschrijft de resultaten van een speurtocht naar contingenties tussen de externe omgeving en de interne organisatie die organisatieprestaties verhogen. In de Angelsaksische literatuur wordt de intra-organisationele sociologie vaak aangeduid met het paraplu-begrip 'organisatiestructuur' (in het Engels ongelukkig 'organization theory' genoemd). Grosso modo kan worden gezegd dat deze traditie zich vooral concentreert op de relatie tussen formele ontwerpeigenschappen van organisaties zoals organisatiestructuur, hiërarchieën en (de)centralisatie enerzijds, en contingenties zoals leeftijd, omvang en technologie anderzijds (Daft, 1992).

$\mathrm{Na}$ mij te lang te hebben gedragen als de Linnaeus ${ }^{15}$ van de organisatiewetenschappen, is het hoog tijd om de lijn van het betoog weer op te pakken. Hopelijk maakt de classificatie het echter beter mogelijk om het voorgaande en het navolgende te plaatsen.

15 Als een uit de klei getrokken $\beta$-VWO'er van na de mammoetwet - en dus zonder enige kennis van de (klassieke) geschiedenis en de klassieke talen - heb ik de neiging om ae en ea in willekeurige verhoudingen door een tekst te strooien. Ik hoop dat het in ieder geval hier goed is gedaan. Om vergelijkbare redenen spreek ik liever van collega's en schema's dan van collegae en schemata. 


\section{Drie voorbeelden van kwantitatief onderzoek}

De organisatiewetenschappen kennen niet alleen een multidisciplinaire oriëntatie, maar zijn ook uitermate eclectisch of - negatief geformuleerd - fragmentarisch van karakter (Pfeffer, 1993). Deze stand van zaken is ook terug te vinden in het brede spectrum van methodologische benaderingen dat $k$ wartaal na kwartaal in de enorme hoeveelheid wetenschappelijke tijdschriften figureert. Met het onderzoek dat ik voorsta en uitvoer - vaak in samenwerking met Maastrichtse vakgenoten - is het niet anders gesteld. De drie hofleveranciers - economie, psychologie en sociologie - fungeren in allerlei mengvormen als inspiratiebron, met gebruikmaking van kwalitatieve en kwantitatieve onderzoekbenaderingen. Toch streef ik hierbij een accentverschuiving na in de richting van economisch-kwantitatief onderzoek. Ik denk dat zonder overdrijving kan worden gesteld dat binnen de organisatiewetenschappen in Nederland de economisch-kwantitatieve benadering nog in de kinderschoenen staat. Het merendeel van mijn Nederlandse collega's heeft zich toegelegd op de ontwikkeling van conceptueelverbale theorieën in combinatie met $\mathrm{kwalitatief-empirische} \mathrm{gevalstudies.}$ Deze benadering is zonder meer legitiem en waardevol. Echter: in aansluiting op internationale ontwikkelingen lijkt het raadzaam om het hierbij niet te laten. Juist door middel van kwantitatief-empirische en theoretische studies is het mogelijk het stadium van exploratief onderzoek te passeren. Over de nadruk op de economische invalshoek heb ik hiervoor al het één en ander gezegd. In het navolgende worden bij wijze van illustratie drie voorbeelden van (economisch-)kwantitatief onderzoek kort aangestipt. Hopelijk heeft deze uiteenzetting ook tot gevolg dat de centrale gedachtengang - aanpassing door organisaties via het afwegen van flexibiliteit en inertie - wat meer tot leven komt.

De kwantitatieve benadering komt tot uitdrukking in zowel het empirische als het theoretische onderzoek. Laat ik met het laatste beginnen. In tegenstelling tot in de organisatiepsychologie en -sociologie is het in de organisatie-economie gebruikelijk theorieën vorm te geven met gebruikmaking van de wiskunde. Een oppervlakkige blik in een willekeurig leerboek in de industriële organisatie, zoals Tirole (1988), maakt dit direct duidelijk. Ook het flexibiliteit-inertiedilemma laat zich modelleren. Ruwweg kan worden gesteld dat de onderzoekstrategie hierbij is om gedragswetenschappelijke bevindingen te introduceren in speltheoretische modellen door de veronderstellingen inzake de drijfveren van economische agenten (en eventueel de restricties waarmee zij zich geconfronteerd zien) aan te passen. Een voorbeeld kan dit illustreren. 


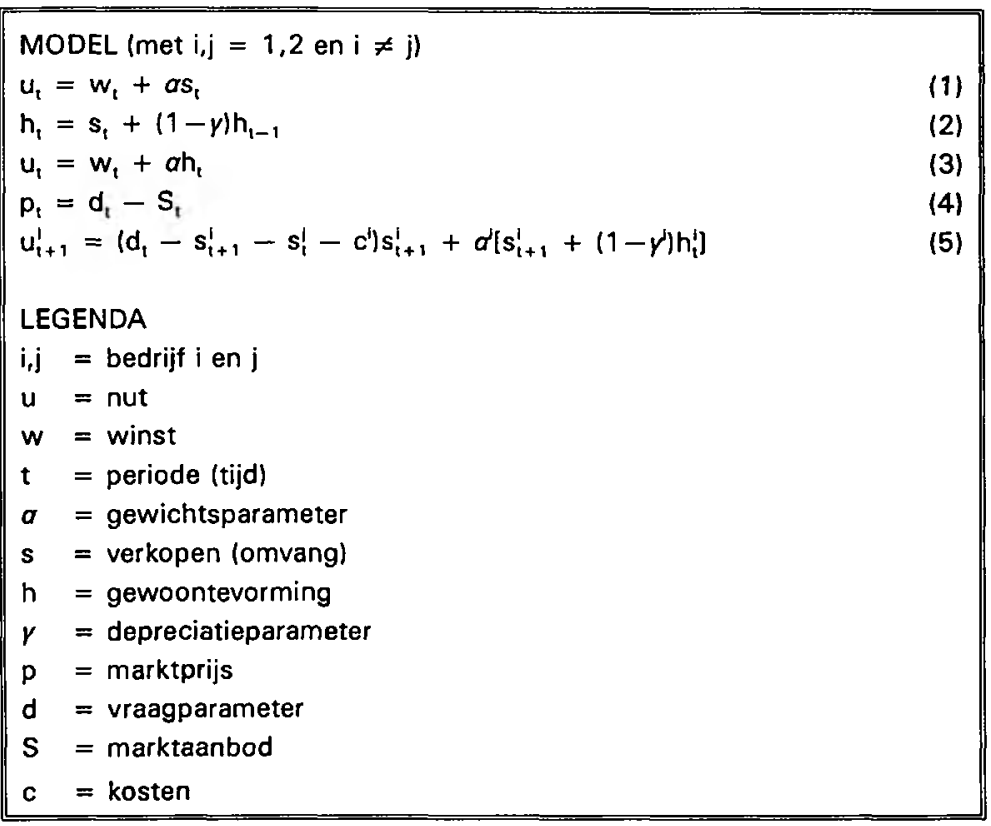

Bron: Van Lier \& Van Witteloostuijn (1993).

Box 1. Een wiskundig model van concurrentie tussen inerte ondernemingen

Het voorbeeld betreft een wiskundige analyse van de effecten van inertieverschillen tussen ondernemingen in een marktomgeving. Het heeft weinig zin om op deze plaats diep in te gaan op het mathematische model zelf. De liefhebber wordt verwezen naar box 1 en de gedetailleerde uitwerking in Van Lier \& Van Witteloostuijn (1993). Voor diezelfde liefhebber wordt in het navolgende regelmatig naar het model in box 1 verwezen. De intuïtie achter het model en de resultaten is als volgt.

Het model kan worden gezien als een drietrapsraket. De basisgedachte - de eerste trap - van de modelexercitie is dat in navolging van bijvoorbeeld Baumol (1963), Marris (1964) en Williamson (1964) het zinvol is af te wijken van de gebruikelijke micro-economische (of neoklassieke) veronderstelling van zuivere winstmaximalisatie. In concreto: ondernemingen - of het uitvoerend management daarvan - streven niet alleen naar hoge winsten, maar ook naar groei [vergelijking (1) in box 1]. Binnen de organisatiewetenschappen - bijvoorbeeld in de 
gedragstheorie van organisaties - is deze gedachtengang van oudsher gemeengoed. Hierbij blijft het niet. De tweede trap van de raket is de introductie van gewoontevorming [vergelijking (2) in box 1]. Hierbij wordt aangenomen dat het management van een onderneming eraan went te groeien (of, vanuit een statisch perspectief, groot te zijn). ${ }^{16}$ Groei nu doet verlangen naar groei straks, en krimpen is moeilijk. In dit verband is het tekenend dat veel bedrijven in de praktijk grote moeite blijken te hebben met beslissingen om uit te treden (Porter, 1976; en Meyer \& Zucker, 1989). Het is overigens opvallend dat veel beloningssystemen deze neiging in de hand werken door een bonus te verstrekken op basis van verkoopvolumes en groeipatronen (Scherer \& Ross, 1990). De derde en laatste trap van de raket is gebaseerd op de veronderstelling van wat kortzichtigheid kan worden genoemd (in 'dure' economentaal: myopische verwachtingen): de bedrijven houden geen rekening met (de effecten van) de gewoontevorming in de toekomst [vergelijking (3) in box 1]. In veel economische modellen wordt ervan uitgegaan - ten onrechte (Akerlof, 1991) - dat agenten bij hun beslissingen nu rekening houden met alle mogelijke consequenties straks. De dagelijkse praktijk van het management staat echter bol van mispercepties en mistaxaties (Zajac \& Bazerman, 1991). Het is belangrijk om in te zien dat in het model inertie is opgenomen in de vorm van (kortzichtige) gewoontevorming ten aanzien van groei (of omvang): de ondernemingen hebben immers moeite met het terugschroeven van het produktievolume.

Bedrijven opereren niet in isolement, maar in onderlinge concurrentie. Ik wil mij vandaag beperken tot concurrentie tussen twee bedrijven: een (Cournot) duopolie. ${ }^{17}$ Beide bedrijven beslissen in elke periode over de hoeveelheid produkten die zij op de markt zullen aanbieden. Op de markt wordt vervolgens de prijs vastgesteld [vergelijking (4) in box 1]. Hiermee is het model gesloten, en is het mogelijk evenwichten te berekenen [op basis van de beslisregel (5) in box 1]. Bij wijze van voorbeeld is het zinvol om twee van het grote aantal mogelijke uitkomsten kort te bespreken. Hierbij onderscheid ik gemakshalve een inert bedrijf (met een lage $\alpha$ ) en een flexibele concurrent (met een hoge

16 De wiskundige modellering van gewoontevorming heeft vooral wortel geschoten in de economische theorieën van arbeidsaanbod (Vendrik, 1993) en consumentengedrag (Alessie \& Kapteyn, 1991). Het voorbeeld uit box 1 is een eerste toepassing op producentengedrag.

17 In Van Lier \& Van Witteloostuijn (1993) wordt ook het geval met n (n $>2$ ) bedrijven geanalyseerd. Voor de teneur van de bevindingen maakt deze complicatie niet veel uit. 
$\alpha$ ), die beide meer of minder efficiënt (lage of hoge c) kunnen zijn. In de eerste plaats is het mogelijk dat het inerte bedrijf winstgevender is dan de flexibele concurrent, of dat het inerte bedrijf zelfs overleeft ten koste van de flexibele rivaal. In de tweede plaats mag niet worden uitgesloten dat de inefficiënte en inerte onderneming marktleider wordt, of dat het efficiënte en flexibele bedrijf van de markt wordt verdreven door de inefficiënte en inerte concurrent. In beide gevallen is een onderneming erbij gebaat inert te zijn! Deze bevinding is een duidelijke ondersteuning van de controversiële voorspelling van de in paragraaf 2 geschetste organisatie-ecologie.

Laat ik nog een stap verder gaan. Het model laat toe een 'optimale' graad van inertie te berekenen: gegeven het inertieniveau van de concurrent kan een onderneming uitrekenen met welke graad van inertie zijzelf de hoogste winsten kan boeken. In figuur 1 wordt deze gedachtengang nader geilllustreerd.

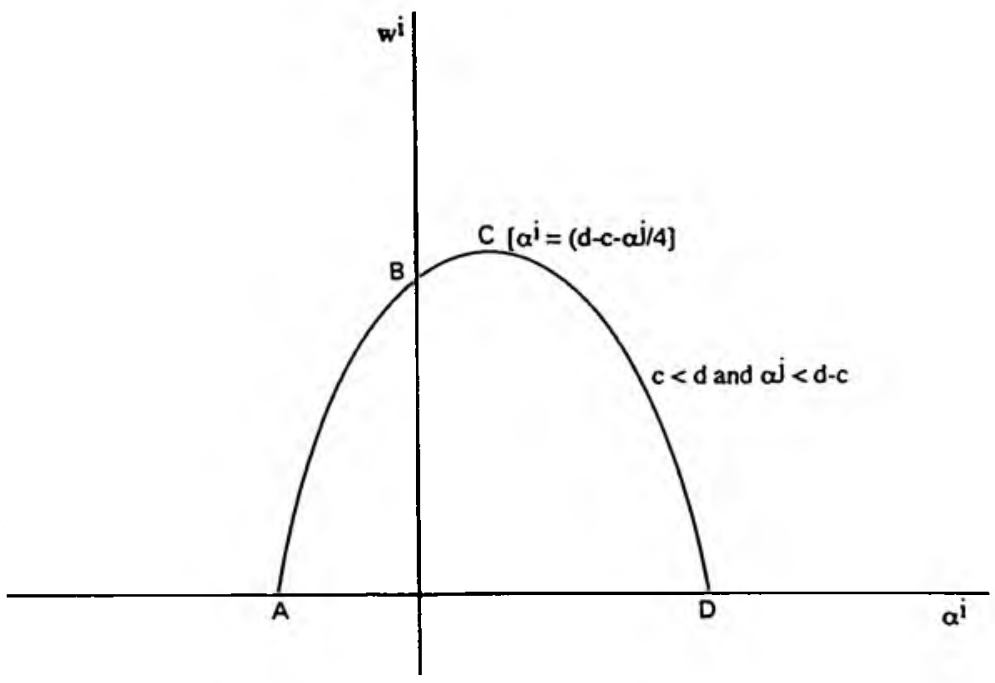

Bron: Boone \& Van Witteloostuijn (1994).

Figuur 1. Het winstmaximaliserende inertienivean

In figuur 1 is punt $C$ het winstgevende optimum voor bedrijf $i$ : in het optimum ziet onderneming i af van een doelstelling die alleen winstmaximalisatie impliceert [ $\alpha^{i}>0$ in vergelijking (1) in box 1]. De 
paradox is weer compleet: de winstgevendheid van een onderneming kan worden bevorderd door de instelling van een managementteam dat winsten juist niet hoog in het vaandel heeft staan (zie ook Vickers, 1985)!

Het voorbeeld van kwantitatief-theoretisch onderzoek in de organisatiewetenschappen heeft hopelijk de vruchtbaarheid van deze onderzoekstrategie - vertrekkend vanuit het economische perspectief - voldoende aangetoond. De (economisch-)wiskundige benadering biedt een aantal voordelen. Laat ik een tweetal voordelen kort aanstippen. In de eerste plaats legt een wiskundige analyse eventuele logische redeneerfouten haarscherp bloor, waarbij regelmatig verrassende verbanden kunnen worden getraceerd. In de tweede plaats maakt wiskundige deductie het mogelijk om precies aan te geven onder welke specifieke omstandigheden welke specifieke uitkomsten worden gegenereerd. Naast kwantitatief-theoretisch onderzoek wil ik echter ook een pleidooi houden ten faveure van kwantitatief-empirische benaderingen. Twee voorbeelden kunnen ter illustratie dienen.

Een eerste voorbeeld is een studie naar de lange-termijnontwikkeling van de bedrijfstak voor accountancy in Nederland (Maijoor, Buijink, Van Witteloostuijn \& Zinken, 1993). Bij de analyse van de data staat het gebruik van de econometrie van tijdreeksen centraal. Op basis van vooral ledenlijsten van beroepsverenigingen zijn kengetallen van accountancykantoren sinds het prille begin van de bedrijfstak in $\mathbf{1 8 8 0}$ tot het laatste decennium van deze eeuw in 1990 verzameld. Het fundament van het databestand bestaat uit een reeks gegevens over individuele accountants. Vervolgens kunnen moeiteloos bedrijfs- en bedrijfstakgegevens worden geconstrueerd. Ik wil met de ontwikkeling op bedrijfstakniveau beginnen. In figuur 2 staat het verloop van twee cruciale kengetallen weergegeven: concentratie en dichtheid. De concentratiegraad, een centraal concept in de economische theorie van de industriële organisatie, is gemeten via het marktaandeel van de vier grootste kantoren. Dichtheid, een cruciale variabele in de sociologische organisatie-ecologie, is simpelweg het aantal kantoren.

Vooral in de afgelopen, zeg, vijfentwintig jaar is een opvallende ontwikkeling zichtbaar: de concentratiegraad en dichtheid lopen gelijktijdig op. Met andere woorden: naast een beperkt aantal steeds groter wordende marktleiders bestaat een groeiende marktnis met zeer veel kleine kantoren. De industrieel-econoom Sutton (1991) noemt dit een 'duale marktstructuur', terwijl de organisatie-ecologen Baum \& Mezias (1991) reppen van 'gelokaliseerde concurrentie' (Boone \& Van 
Witteloostuijn, 1995). In Maijoor, Buijink, Van Witteloostuijn \& Zinken (1993) worden voor deze ontwikkeling twee mogelijke verklaringen aangedragen: (i) de accountancymarkt volgt slechts een dualisering in de markten van de klantengroepen; en (ii) nieuwe wetgeving inzake verplichte winkelnering (met name in de sfeer van de goedkeuring van jaarrekeningen) heeft een duale vraag geïnstitutionaliseerd. Vooral deze tweede verklaring is in de huidige context interessant: zij impliceert immers een inertie op het niveau van de geaggregeerde marktvraag. Of, met andere woorden: verplichte winkelnering introduceert een inertie op bedrijfstakniveau waarvan alle kantoren kunnen profiteren. Weer: inertie helpt, zij het dit keer op bedrijfstak- in plaats van organisatieniveau!

Maar laat ik terugkeren naar het niveau van de organisaties: welke accountantskantoren doen het goed, en waarom? Gezien de duale structuur in de bedrijfstak is het nuttig hierbij een onderscheid te maken tussen de grote en de kleine kantoren. Laat ik beginnen met de grote kantoren. In tabel 4 staat de top-vijf van accountantskantoren voor elk jaar in de periode 1964-1990 weergegeven (Maijoor \& Van Witteloostuijn, 1993). Wat meteen opvalt, is de grote stabiliteit van deze top-vijf. Afgezien van positiewisselingen binnen de top-vijf, is het slechts een enkeling gelukt tot dit walhalla van de accountancymarkt toe te treden. Deze zeldzame toetredingen zijn notabene het resultaat van fusies tussen top-vijfkantoren. Een voorbeeld is de toetreding van VB in 1990 na de fusie tussen Dijker Van Dien en Coopers \& Lybrand. Waarom lukt het de grote kantoren om hun toppositie decennialang vast te houden $?^{18} \mathrm{En}$, daaraan voorafgaand: waarom zijn het juist deze kantoren die een dergelijke benijdenswaardige positie hebben weten te bereiken? Misschien dat ook hier weer de afweging tussen flexibiliteit en inertie - en dus het leervermogen van organisaties - een verklaring kan bieden. Hierop kom ik terug nadat ik kort ben ingegaan op het wel en wee van de kleine kantoren.

18 Merk op dat hierbij sprake is van een inertie op mesoniveau: dat van de strategische groep van top-vijfbedrijven. 

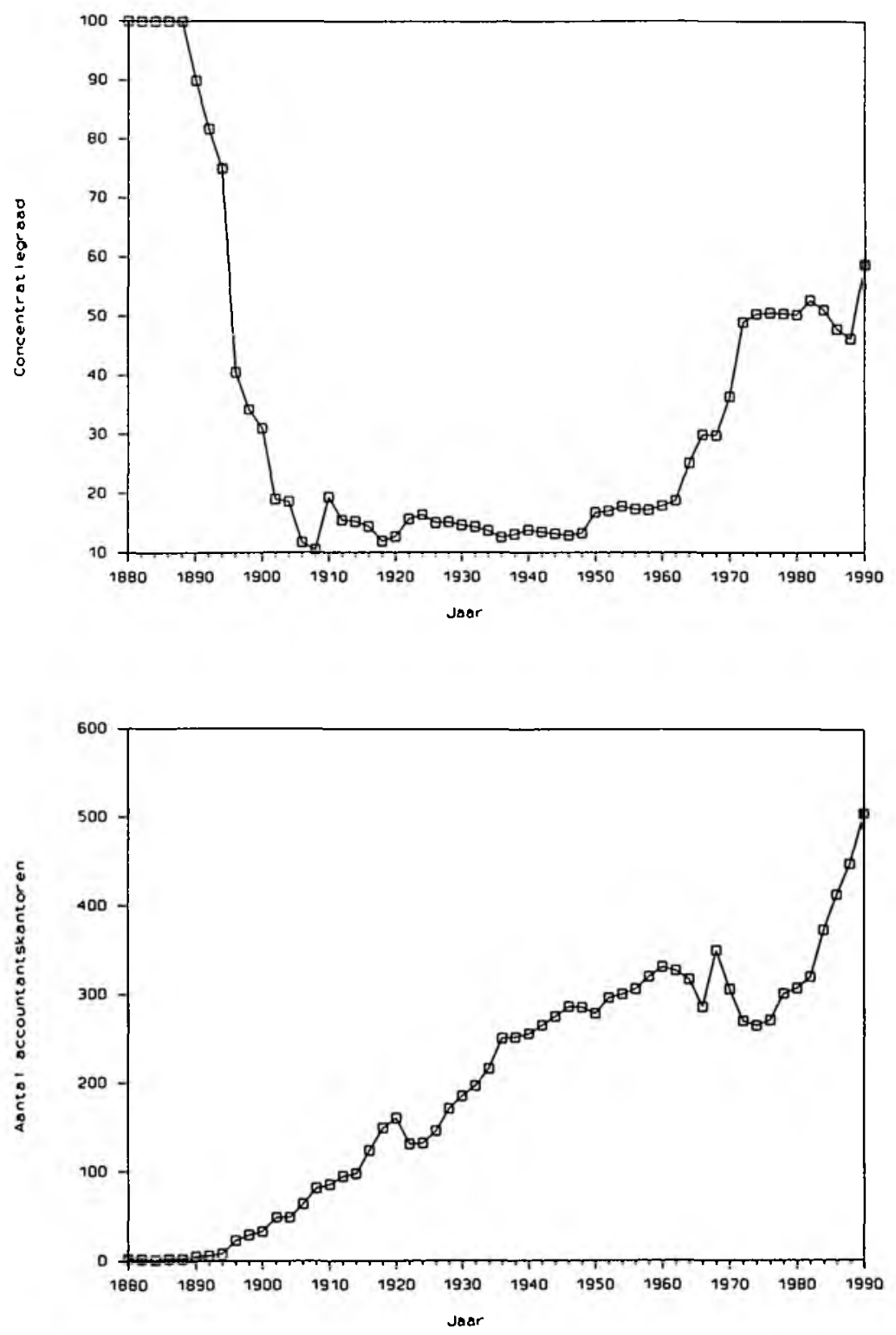

Bron: Maijoor, Buijink, Van Witteloostuijn \& Zinken (1993).

Figuur 2. Concentratie en dichtheid in de Nederlandse accountancymarkt in de periode $1880-1990$ 


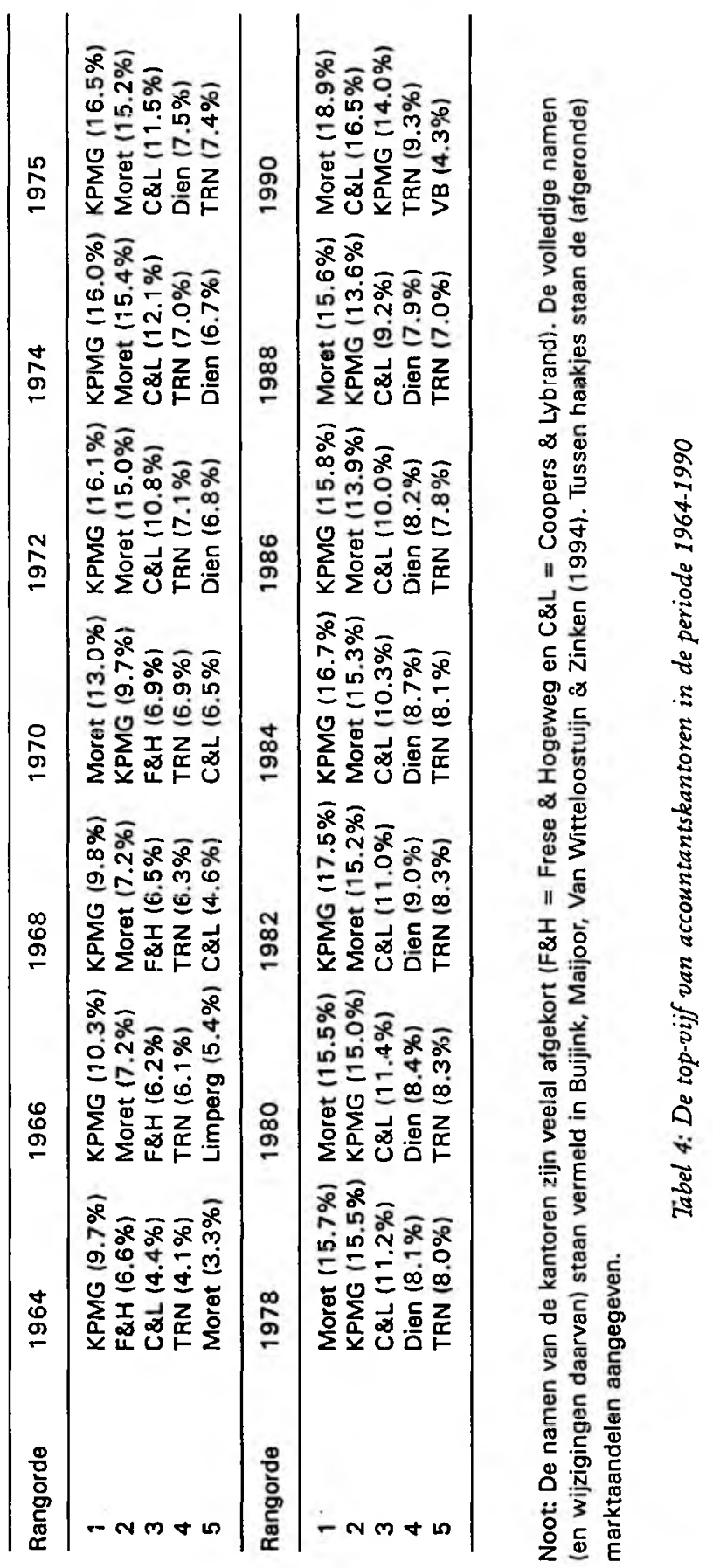




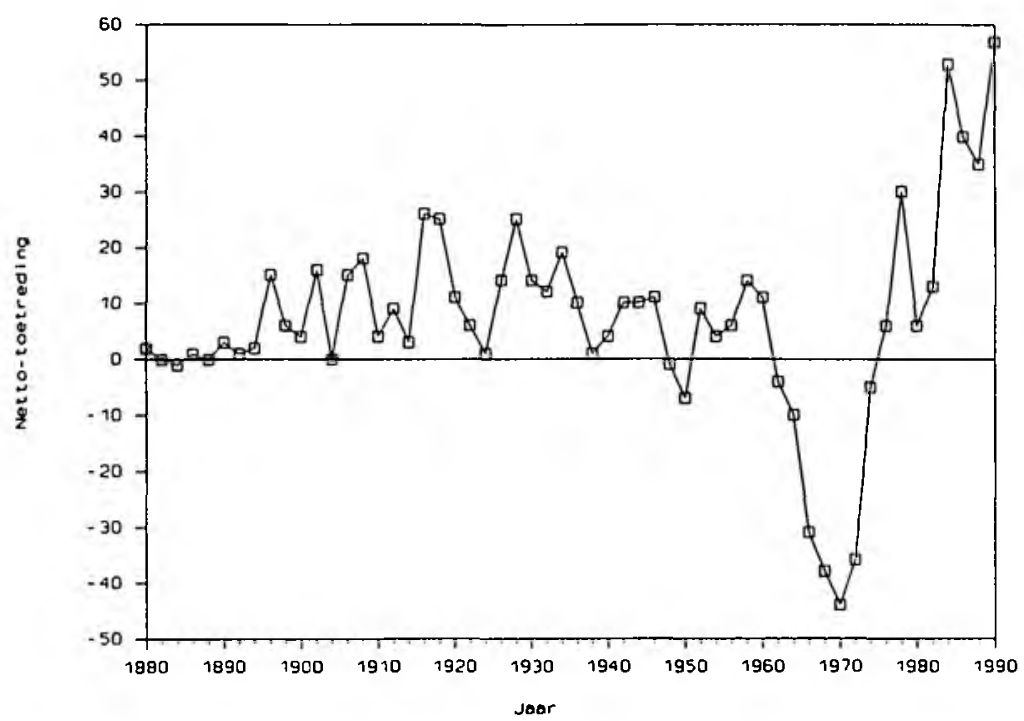

Bron: Maijoor, Buijink, Van Witteloostuijn \& Zinken (1993).

Figuur 3. Nettotoetreding in de Nederlandse accountancymarkt in 1880-1990

De dynamiek in het marktsegment met de kleine kantoren is indrukwekkend. Het lijkt wel alsof een voortdurend komen en gaan van kantoren dit segment kenschetst. Uit figuur 3 blijkt dat de nettotoetreding (het aantal toetredingen minus het aantal uittredingen) de laatste decennia alles behalve verwaarloosbaar is geweest. In de periode 19681970 is bijvoorbeeld sprake van 26 toetredingen en 70 uittredingen op een totaal aantal kantoren van 350 in 1968 . Ook hier dringt zich weer de vraag op waarom bepaalde kantoren het weten te redden (en misschien zelfs weten te groeien) en andere niet.

Deze combinatie van fenomenen - het succes van de bedrijfstak als geheel, de grote stabiliteit van de top-vijf en de aanzienlijke dynamiek in het segment met de kleine kantoren - verlangt een verklaring. Op dit moment is de speurtocht naar mogelijke verklaringen nog niet afgerond. Het is echter waarschijnlijk dat ook hier het flexibiliteitinertiedilemma een cruciale rol speelt. Laat ik bij wijze van illustratie twee hypothesen noemen. In de eerste plaats is het succes van de bedrijfstak als geheel mogelijk het gevolg van bedrijfstakinerties. Vooral de verplichte winkelnering springt hierbij in het oog: in de afgelopen vijfentwintig jaar is het aan steeds grotere groepen organisaties van 
steeds geringere omvang wettelijk verplicht gesteld om jaarrekeningen goed te laten keuren door accountants. In de tweede plaats mag niet worden uitgesloten dat het duurzame succes van de grote kantoren is toe te schrijven aan twee, gerelateerde, fenomenen: (i) kantoren die vroegtijdig (in de jaren vijftig) en vasthoudend (tot in de jaren negentig) een actief acquisitie- en fusiebeleid hebben ingezer, zijn doorgedrongen tot de groep van marktleiders; en (ii) de grote kantoren hebben grote klanten aan zich weten te binden. De eerste verklaring duidt op de tijdige keuze van wat later de optimale koers is gebleken: de betrokken kantoren hebben zich vroeg verplicht, in de termen van paragraaf 2 en 3 , tot een krachtdadige fusie- en acquisitiestrategie. De tweede verklaring is ook weer een inertie: klanten wisselen slechts bij hoge uitzondering van accountant. Dus, het wordt eentonig, inertie helpt!

Het tweede voorbeeld van kwantitatief-empirisch onderzoek heeft betrekking op een studie naar besluitvorming door en leergedrag van (groepen van) individuele economische agenten in de context van concurrentie. Het fundament van het onderzoek is de experimentele economie. Sinds de jaren tachtig wint de experimentele economie snel aan populariteit (Joumal of Economic Behavior and Organization, 1992), ook binnen de industrieel-economische theorie van marktwerking (Plott, 1989) en de micro-economische theorie van besluitvorming (Grether, 1992). Binnen deze traditie worden proefpersonen blootgesteld aan omstandigheden (prikkels) die door de experimentatoren systematisch worden gemanipuleerd. Binnen de experimentele economie is de aandacht vooral (uitsluitend?) uitgegaan naar de effecten van externe omstandigheden op de gedragingen van economische agenten. In de experimentele organisatiewetenschappen kan hieraan de invloed van individuele karakteristieken van (groepen van) beslissers worden toegevoegd. Het experiment in Boone, De Brabander \& Van Witteloostuijn (1994) is een voorbeeld van een dergelijke aanpak.

De experimenten in Boone, De Brabander \& Van Witteloostuijn (1994) hebben tot doel de invloed van objectieve en subjectieve kenmerken van (groepen van) economische beslissers op de neiging tot concurrentie of samenwerking te traceren. Voorbeelden van objectieve kenmerken zijn leeftijd, geslacht en (voor)kennis; subjectieve karakteristieken hebben betrekking op persoonlijkheidseigenschappen. ${ }^{19} \mathrm{De}$ vraag is of, en zo ja: in hoeverre, dergelijke kenmerken van invloed zijn op de mate

19 Met de introductie van subjectieve persoonlijkheidskenmerken wordt getreden in een aloude traditie binnen de psychologie. Zie voor een vroeg overzichtsartikel Pruitt \& Kimmel (1977). 
waarin (groepen van) individuen competitieve of coöperatieve strategieën ontwikkelen. Hierbij vormt het bekende gevangenendilemma de experimentele context. In tabel 5 staat het gehanteerde dilemma geschetst.

Tabel S: Een gevangenendilemma

\begin{tabular}{|c|c|c|}
\hline \multirow{2}{*}{ BEDRIJF I } & \multicolumn{2}{|c|}{ BEDRIJF II } \\
\cline { 2 - 3 } & Lage prijs & Hoge prijs \\
\hline Lage prijs & $(-20,-20)^{\circ}$ & $(800,-400)$ \\
\hline Hoge prijs & $(-400,800)$ & $(600,600)$ \\
\hline
\end{tabular}

- In duizenden guldens.

Twee bedrijven (spelers), I en II, kunnen simultaan (dat wil zeggen: zonder communicatie) ervoor kiezen een hoge of een lage prijs te stellen. De resulterende winsten zijn afhankelijk van de gekozen prijzencombinatie. Hierbij is het belangrijk om te beseffen dat elk bedrijf gebaat is bij de keuzecombinatie waarbij het zelf de lage en de concurrent de hoge prijs stelt, terwijl de gezamenlijke marktwinst wordt gemaximaliseerd indien beide rivalen kiezen voor een hoge prijs. Het stellen van de lage prijs is de competitieve (of agressieve) strategie, en de keuze voor de hoge prijs is de coöperatieve (of vredelievende) strategie.

Het spel is gespeeld in vijf varianten, waarbij de spelomgeving van variant tot variant verandert. Daarnaast zijn tien objectieve en vier subjectieve karakteristieken van de individuele spelers (ongeveer veertig economiestudenten) gemeten. Met uitzondering van het viende spel kennen alle experimenten twaalf ronden. Het voert uiteraard te ver om vandaag alle mogelijke combinaties te bespreken. Laat ik een tweetal illustratieve bevindingen aan $u$ voorleggen, beide in het licht van een specifieke persoonlijkheidskenmerk: perceptie van beheersing ('locus of control': Rotter, $1966 \&$ 1975) ${ }^{20}$ Een individu met een externe

20 Beide gerapporteerde bevindingen hebben betrekking op het effect van een specifiek subjectief persoonlijkheidskenmerk. Het is misschien illustratief om ook van beide andere groepen kenmerken en bijbehorende bevindingen kort een voorbeeld te geven: (1) het herhaald maar eindig, in plaats van eenmalig, spelen van het gevangenendilemma, een verandering van de spelomgeving, leidt ertoe - in tegenspraak met de voorspeiling van de speltheorie! - dat de spelers zich coöperatiever gaan gedragen; en (2) spelers met meer 'harde' 
perceptie van beheersing (een externe) handelt op basis van de veronderstelling dat succes of faling te danken is aan omstandigheden buiten haar of zijn invloedssfeer, terwijl een persoon met een interne perceptie van beheersing (een interne) van het tegendeel uitgaat. Dus: een externe schrijft succes eerder toe aan het toeval, terwijl een interne de verklaring veeleer zoekt in haar of zijn eigen capaciteiten.

Ongeacht de spelomstandigheden blijken internen zich coöperatiever te gedragen dan externen. Deze bevinding is overduidelijk weerspiegeld in figuur 4, waarbij het aantal coöperatieve (en dus ook het aantal competitieve) keuzen kan variëren van nul tot twaalf. Een tweede bevinding is dat internen aanmerkelijk beter in staat blijken hun strategie aan te passen aan de ontwikkelingen die zich in de loop van het spel voordoen. Dit heeft onder meer tot gevolg dat een koppel van interne spelers aanmerkelijk betere resultaten weet te boeken dan een tweetal externen. Dat wil zeggen: twee bedrijven 'onder leiding van' internen blijken veel vaker in staat tot impliciete samenwerking te komen dan andere combinaties. De verschillen staan vermeld in tabel 6.

Tabel 6: Coöperatief gedrag van perceptie-van-beheersingkoppels

\begin{tabular}{|c|c|c|c||}
\hline \multirow{2}{*}{ EXPERIMENT } & \multicolumn{3}{|c|}{ GEMIDDELD AANTAL COÖPERATIEVE KEUZEN } \\
\cline { 2 - 4 } & Twee externen & $\begin{array}{c}\text { Gemengd } \\
\text { koppel }\end{array}$ & Twee internen \\
\hline 1 & 1.20 & 9.67 & 16.00 \\
\hline 2 & 3.30 & 12.50 & 14.25 \\
\hline 3 & 9.80 & 16.67 & 18.00 \\
\hline
\end{tabular}

Noot: Alleen de drie herhaalde spellen zijn in dit verband relevant, waarbij het maximale aantal coöperatieve keuzen 24 ( 2 spelers $\times 12$ ronden) is.

Op basis van deze tweede bevinding kan, voor de verandering, worden geconcludeerd dat flexibiliteit helpt! Of, anders geformuleerd, internen zijn beter in staat snel op basis van ervaringen te kiezen voor de winstgevende beslisregel: het prefereren van samenwerking (hoge

economische voorkennis, een objectief kenmerk, kiezen vaker voor een agressieve strategie dan hun tegenvoeters met minder van dergelijke voorkennis. 
prijzen) boven concurrentie (lage prijzen). ${ }^{21}$ Deze gedachtengang strookt met de conclusie van paragraaf 2: het strategisch management is gericht op het flexibel kiezen van de portefeuille van inerties (hier: de beslisregel in de vorm van een prijsstrategie).

Met de drie voorbeelden van $\mathrm{kwantitatief}$ onderzoek in de organisatiewetenschappen heb ik ten minste drie boodschappen willen uitdragen. In de eerste plaats hoop ik dat de centrale plaats van het flexibiliteitinertiedilemma in de organisatiewetenschappen nog duidelijker is geworden. Ongeacht het niveau van aggregatie - de bedrijfstak, de organisatie of het management - is de speurtocht naar de optimale balans tussen flexibiliteit en inertie essentieel. In de tweede plaats ben ik ervan overtuigd dat juist een disciplinaire kruisbestuiving ${ }^{22}$ - met de economische invalshoek als startpunt - in de toekomst veel onderzoeksvruchten kan afwerpen. ${ }^{33}$ Binnen monodisciplines - en zeker deeltheorieën daarbinnen - is het zo langzamerhand moeilijk substantiële vooruitgang te boeken. In de derde plaats draag ik methodische pluriformiteit - met een accent op kwantitatief onderzoek - hoog in het vaandel. Met name een intensievere gebruikmaking van de kwantitatief-empirische en -theoretische onderzoekmethodologieën is nodig om de organisatiewetenschappen vooruit te helpen.

21 Over het waarom van deze en andere bevindingen worden in Boone, De Brabander \& Van Witteloostuijn (1994) suggesties gedaan.

22 Kruisbestuiving tussen verschillende disciplines van de gedrags- en maatschappijwetenschappen (met name economie, psychologie en sociologie) verloopt in het algemeen alles behalve vlekkeloos. Eenzijdige beschuldigingen (waarbij vooral de controversen hard versus zacht en inductie versus deductie centraal staan) en wederzijdse anklachten (met name van wetenschappelijk imperialisme) zijn hierbij niet van de lucht. In Keizer \& Soeters (1987) worden de pros en cons van integratie binnen de gedrags- en maatschappijwetenschappen uitvoerig belicht. Hoewel op het eerste gezicht juist op het vlak van besluitvorming (door individuen en groepen) de mogelijkheden voor kruisbestuiving legio zijn, lijkt in het bijzonder de economische veronderstelling van rationaliteit een onneembare drempel op te werpen. Van Witteloostuijn (1992) pleit voor wederzijdse vredelievendheid (tabel 5!), waarbij het rationaliteitsdebat [over schijnbare tegenstellingen (Van Witteloostuijn, 1988)?] moet worden omzeild.

23 Ook de drie hiervoor beschreven voorbeelden van kwantitatief onderzoek zijn gebaseerd op disciplinaire kruisbestuivingen. Ik denk dat u zonder veel moeite elk van de drie voorbeeiden kunt plaatsen in twee of drie van de kolommen in tabel 2. 

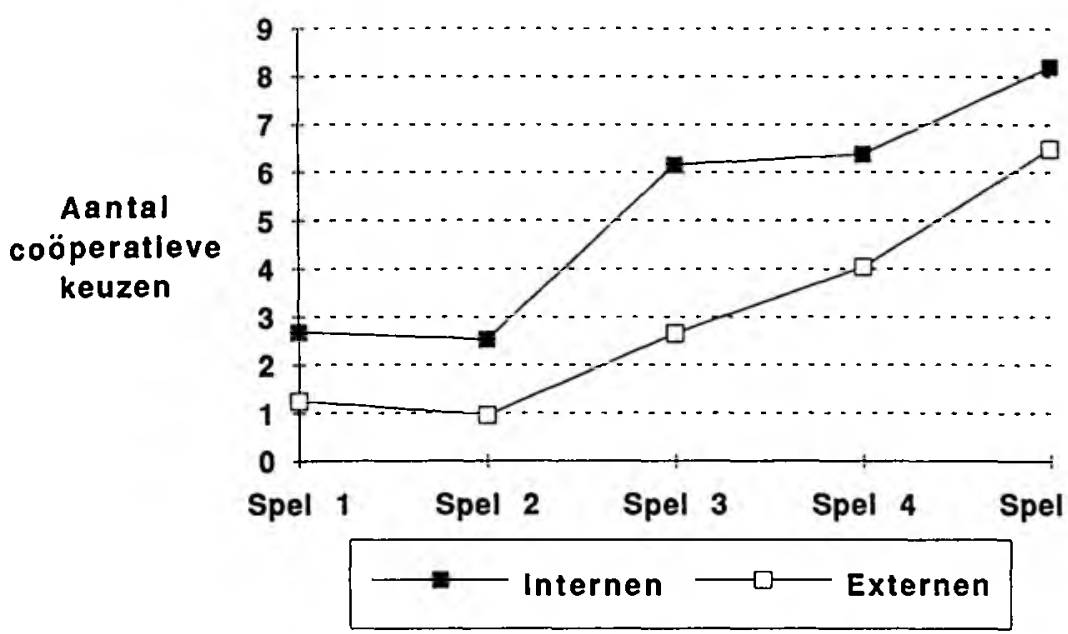

Bron: Boone, De Brabander \& Van Witteloostuijn (1994).

Figuur 4. Het gemiddelde aantal coōperatieve keuzen van externen en internen

\section{Tolerantie en variatie}

Het voorbeeld van de experimentele benadering binnen de organisatiewetenschappen in de vorige paragraaf is - wat mij betreft - intrigerend omdat het de kern van het vak op een heel directe manier treft. Waarom doet de ene beslisser (in een organisatie) het beter dan de andere? Of, breder geformuleerd: waarom doet het ene (top)managementteam het beter dan het andere? Uiteindelijk moet het leervermogen van organisaties worden gevonden in de mensen zelf. Structuren definiëren randvoorwaarden, maar meer ook niet.

Slechts een enkeling zal het oneens zijn met de stelling dat de rol van de dominante coalitie - de leidinggevenden - binnen een organisatie cruciaal is. Binnen een organisatie is het topmanagementteam uiteindelijk verantwoordelijk voor de bepaling van het beleid. Wat kan worden gezegd over het functioneren van een dergelijk team in relatie tot de teamsamenstelling? Alles lijkt erop te wijzen dat het belangrijk is te 
waken voor een te grote uniformiteit. Een groep gelijkgezinden loopt het gevaar zich af te sluiten van de buitenwereld, en niet meer te reageren op signalen uit de externe of interne omgeving die roepen om een reactie. Een homogeen (top)managementteam heeft de neiging vast te roesten in standaardinterpretaties en -strategieën waarover brede consensus is ontstaan.

Een prachtige casusstudie - waarmee nogmaals is gezegd dat ook $\mathrm{kwalitatief}$ onderzoek zeer waardevol kan zijn - van Janis uit 1971 is nog altijd bijzonder illustratief. Tijdens de beroemde Cuba-crisis in 1961 heeft de groep van adviseurs rond president John Kennedy - met grootheden als Robert McNamara en Arthur Schlessinger Jr in hun midden - alle symptomen vertoont van wat Janis groepsdenken ('groupthink') noemt. De groep was dusdanig met zichzelf bezig dat acht symptomen van groepsdenken de kans kregen te ontstaan, zoals onder meer de illusie van onschendbaarheid, het negeren van externe waarschuwingen, het gebruik van stereotyperingen, het gebrek aan zelfcensurering, het uitschakelen van advocaten van de duivel en uiteindelijk - de dwang tot consensus. Janis' voorbeelden van de gevaren van besluitvorming binnen groepen zijn nog altijd overtuigend.

Inmiddels heeft het onderzoek naar het functioneren van topmanagementteams in organisaties een hoge vlucht genomen. In deze topmanagementteamstudies is vooral aandacht besteed aan het belang van de objectieve en/of subjectieve kenmerken van de topmanager zelf (in de Nederlandse context veelal de voorzitter van de Raad van Bestuur) of van de samenstelling van het voltallige team in termen van dergelijke kenmerken (Boone, De Brabander \& Van Witteloostuijn, 1993). Wat is bijvoorbeeld de invloed van de ambtstermijn, loopbaanverloop en functionele achtergrond (objectieve kenmerken) of de persoonlijkheid, managementstijl en sociale cohesie (subjectieve kamakteristieken) van de topmanager en de teamleden op de effectiviteit van de besluitvorming of de aard van geformuleerde strategie? In het verlengde van de experimentele studie die is besproken in de vorige paragraaf, is bijvoorbeeld gebleken dat interne topmanagers betere resultaten behalen dan hun externe collega's (Miller \& Toulouse, 1986; en Boone \& De Brabander, 1993). In het kader van het flexibiliteitinertiedilemma is onder meer de bevinding van Finkelstein \& Hambrick (1990) interessant dat managementteams met een gemiddeld lange ambtstermijn inert zijn, en nauwelijks wijzigingen in de strategische koers aanbrengen of afwijkingen van bedrijfstaknormen toestaan. In het algemeen kan worden geconcludeerd dat flexibiliteit van (top)managementteams gebaat is bij heterogeniteit: variatie in leeftijden, ambtster- 
mijnen, functionele achtergronden, persoonlijkheden en dergelijke, helpt groepsdenken en inertie te voorkomen.

Kortom: een succesvol topmanagementteam (of welke taakgroep dan ook) is tolerant. Het Latijnse tolerantie en tolereren betekenen 'verdraagzaamheid jegens andersdenkenden' respectievelijk 'dulden' en 'toelaten' (van Dale). Dat is precies wat een succesvol (top)managementteam kenmerkt. Hierbij is een heterogene samenstelling van de groep belangrijk, waarbij het elk lid van de groep is toegestaan om de rol van de advocaat van de duivel te spelen. In een heterogeen samengesteld (top)managementteam worden niet alleen sneller nieuwe ontwikkelingen opgemerkt, maar zijn de teamleden ook meer bereid om open over alternatieven te spreken. Met andere woorden: op het niveau van het (top)managementteam is inertie juist uit den boze!

\section{Besluit}

$\mathrm{U}$ heeft inmiddels drie kwartier mijn woordenbrij moeten tolereren. Maar wat heb ik eigenlijk gezegd? Of, vriendelijker geformuleerd: wat kan nu worden geconcludeerd? In ieder geval dat voor verveling geen tijd is. Daarnaast bevat het betoog een pleidooi voor tolemantie en variatie, zowel binnen als rond organisaties: binnen organisaties, omdat veelzijdigheid en alertheid helpen te overleven; rond organisaties, zodat selectieprocessen hun werk kunnen doen. Om te overleven moeten organisaties een balans vinden en behouden tussen flexibiliteit enerzijds en inertie anderzijds. Het is de bestudering van de gelijktijdige werking van twee processen - de externe selectie via de tucht van de markt en het interne leervermogen van organisaties - die de organisatiewetenschappen boeiend en complex maken. ${ }^{24}$

24 Het idee van economische selectie is eeuwenoud. In dit verband is het aardig om te vermelden dat de grondlegger van de biologische selectietheorie - Darwin - zich onder meer heeft laten inspireren door het werk van de econoom Malthus (1798). In feite is de gedachte van economische selectie bij alle '(neo-)klassieke' economen terug te vinden, zelfs bij de meest 'statische' van allemaal: Walras [1874: zie hierover Van Witteloostuijn \& Maks (1989 \& 1990)]. Een bekende amhanger van het gedachtengoed van economische selectie in het begin van deze eeuw is natuurlijk Schumpeter (1943). Zijn korte hoofdstuk VII (slechts zes bladzijden!) is de ultieme samenvatting van de centrale gedachtengang. Eigenlijk kan gezegd worden dat de huidige aandacht voor (economische) selectie terug is van nooit weggeweest. Overigens is ook de sociologische organisatie-ecologie een selectietheorie. 
Het voorgaande betoog heeft laten zien dat de afweging tussen flexibiliteit en inertie op ten minste drie niveaus van aggregatie ${ }^{25}$ terugkomt, waarbij de gewenste balans kan verschillen voor de korte(re) en lange(re) termijn ${ }^{26}$. Natuurlijk is het moeilijk te geloven dat hierbij universele wetten bestaan. Elke organisatiewetenschapper is daarvoor te veel opgegroeid met allerlei varianten van de contingentietheorie. Desalniettemin staan in tabel 7 de conclusies ongenuanceerd samengevat. Op deze plaats voert het te ver om aandacht te besteden aan de uitzonderingen op de regel. Ik hoop echter dat de stellingen in tabel 7 hun werk als ijkpunt kunnen doen.

De conclusies zijn verwoord vanuit het perspectief van een gevestigde organisatie. Dat wil zeggen: is een zittende organisatie gebaat bij flexibiliteit of inertie? ? $^{2}$

Met een korte toelichting van tabel 7 per aggregatieniveau wil ik deze oratie besluiten.

1. Op het niveau van de bedrijfstakomgeving zijn gevestigde organisaties gebaat bij inertie, zowel op de korte(re) als de lange(re) termijn. Een illustratief voorbeeld van een bedrijfstakinertie zijn toetredingsbelemmeringen, waaraan in paragraaf 2 kort aandacht is besteed. Dergelijke belemmeringen maken het voor nieuwe organisaties moeilijk om vaste grond onder de voet te krijgen. Een tweede voorbeeld is te vinden in de in paragraf 4 besproken accountancymarkt. De verplichte winkelnering in deze bedrijfstak verzekert de zittende kantoren van een omvangrijke vraag naar hun diensten. In het algemeen kan worden gezegd dat bedrijfstakinertie het voor de zittende ondernemingen eenvoudiger maakt om hun gevestigde

25 Kortheidshalve beperk ik mij tor drie aggregatieniveaus. Natuurlijk valt ook over andere niveaus van aggregatie wat te zeggen (denk bijvoorbeeld aan de strategische groepen in het voorbeeld van de in paragraaf 4 besproken accountancymarkt). In termen van het flexibiliteit-inertiedilemma denk ik echter dat de conclusies voor andere aggregatieniveaus niet zullen afwijken van de stellingen in tabel 7 (in deze context is het verschil tussen de bedrijfstakomgeving en de strategische groepen bijvoorbeeld slechts gradueel).

26 De begrippen korte en lange termijn verwijzen niet naar kalendertijd. Het zijn analyrische concepten in de zin van Marshall (1920) die het mogelijk maken kwalitatieve verschillen in de sfeer van beslisvariabelen te traceren.

27 Met een verhandeling over toetreding zou de oratie ook moeiteloos te vullen zijn geweest. Daarbij zou ik bijvoorbeeld de lijnen uitgezet in Van Wegberg \& Van Witteloostuijn (1992), Van Witteloostuijn \& Van Wegberg (1992) en Van Witteloostuijn (1993) hebben kunnen volgen. 
posities te behouden. Het deelterrein van de externe organisatie richt zich op de inventarisatie en analyse van dergelijke inerties in de omgeving. ${ }^{28}$

Tabel 7: Gewenste flexibiliteit (inertie) door een gevestigde organisatie

\begin{tabular}{||c|c|c|l||}
\hline \multirow{2}{*}{$\begin{array}{c}\text { NIVEAU } \\
\text { VAG } \\
\text { AGREGATIE }\end{array}$} & \multicolumn{2}{|c|}{ TERMIJN } & $\begin{array}{l}\text { DEELTERREIN } \\
\text { VAN DE } \\
\text { ORGANISATIE- } \\
\text { WETENSCHAPPEN }\end{array}$ \\
\cline { 2 - 4 } & Kort(er) & Lang(er) & $\begin{array}{l}\text { Externe } \\
\text { organisatie }\end{array}$ \\
\hline Bedrijfstakomgeving & Inertie & Inertie & $\begin{array}{l}\text { Strategisch } \\
\text { management }\end{array}$ \\
\hline Organisatiestrategie & Inertie & Flexibiliteit & $\begin{array}{l}\text { Interne } \\
\text { organisatie }\end{array}$ \\
\hline Managementteam & Flexibiliteit & Flexibiliteit \\
\hline
\end{tabular}

2. Op het niveau van de organisatiestrategie is het flexibiliteit-inertiedilemma complexer. Aan de ene kant is een strategie op de korte(re) termijn alleen geloofwaardig wanneer zij gepaard gaat met verplich-

28 Zeker op het niveau van de bedrijfstak zou u kunnen twijfelen aan de geldigheid van de stellingen in tabel 7 . Deze twijfel dringt zich misschien vooral op in het licht van het functioneren van factormarkten. Wordt immers niet sinds jaar en dag alom - ook door het bedrijfsleven - geklaagd over bijvoorbeeld de inerte arbeidsmarkt in Nederland? Ook hier is het dilemma echter complexer dan het op het eerste gezicht lijkt. De roep om flexibilisering van de arbeidsmarkt vanuit de Nederlandse bedrijfswereld wordt vooral ingegeven door klachten over de teruglopende internationale concurrentiekracht. Het probleem is dus niet de gebrekkige flexibiliteit op zich, maar verscbillen in flexibiliteit tussen landen. Ceteris paribus, dat wil zeggen: zonder dergelijke verschillen, kan worden aangetoond dat gevestigde ondernemingen juist gebaat zijn bij een inerte arbeidsmarkt - bijvoorbeeld in de vorm van hoge CAO-lonen - omdat daarmee potentiële toetreders buiten de markt worden gehouden (Gollier, 1991). Een tweede voorbeeld is de kapitaalmarkt. Het is niet voor niets dat veel beursgenoteerde ondernemingen zelf inerties inbouwen in de vorm van allerlei creatieve beschermingsconstructies om een vijandige overneming te voorkomen of in ieder geval te bemoeilijken. Daarnaast profiteren gevestigde ondernemingen van de hogere drempel voor nieuwkomers op de kredietmarkt (Poitevin, 1989). In het algemeen is het overigens opmerkelijk hoe vaak gevestigde organisaties zelf aan de overheid vragen om bedrijfstakinerties in het leven te roepen. Hiervan is de voortdurende roep om afscherming van thuismarkten vanwege 'oneerlijke' concurrentie uit het buitenland een sprekend voorbeeld. 
tingen. Aan de andere kant is het noodzakelijk om de portefeuille van verplichtingen regelmatig kritisch tegen het licht te houden, en desgewenst aan te passen. Over deze spanning - korte-termijninertie versus lange-termijnflexibiliteit - is in paragraf 2 voldoende gezegd. In de gestileerde omgeving van het speltheoretische model van concurrentie tussen inerte ondernemingen in paragraaf 4 (box 1) is het zelfs mogelijk gebleken om een 'optimale' graad van inertie te berekenen. Binnen het deelterrein van het strategisch management wordt voortdurend gezocht naar deze subtiele balans tussen flexibiliteit en inertie.

3. Op het niveau van het managementteam is het flexibiliteit dat hoogtij viert. Een succesvol managementteam (of welke taakgroep dan ook) staat open voor nieuwe ontwikkelingen, en is bereid om de gebruikelijke (vaak vastgeroeste) mutines ter discussie te stellen. Het managementteam moet tolerant zijn voor afwijkende gezichtspunten. Alertheid door openheid en tolerantie maakt het mogelijk mispercepties en mistaxaties te voorkomen of tijdig te corrigeren. De in paragraf 5 besproken topmanagementteamstudies maken dat duidelijk. Daarnaast zijn de bevindingen in de context van het in paragraaf 4 besproken experiment met het gevangenendilemma illustratief. Vanuit het deelterrein van de interne organisatie worden keer op keer inzichten aangedragen die de noodzakelijke flexibiliteitvan taakgroepen in het algemeen en managementteams in het bijzonder benadrukken. ${ }^{29}$

\section{Intermezzo III}

Het woord tolerantie is niet onbekend - op zijn zachtst gezegd - in geschriften over Nederland. Wetenschappelijke artikelen en journalistieke kolommen worden keer op keer aan dit thema gewijd. Met de mond belijden is mooi, maar wat betekent het in de praktijk van alledag? Als de Nederlandse samenleving werkelijk zo tolerant is - en daaraan valt te twijfelen in het licht van de versnelde toeneming van de aanhang van extreem rechts in de afgelopen maanden -, geldt dit dan ook voor de samenlevingen in organisaties en binnen groepen van organisaties? En, nog een stap verder: impliceert dit vervolgens - vergelijkenderwijs - dat Nederlandse organisaties groeien en bloeien? Helpt het een organisatie verder om cultureel tolerant te zijn? In dit verband wil ik $u$ de bevindingen van Cox, Lobel \& McLeod (1991) niet onthouden. Met behulp van

29 Het moge duidelijk zijn dat wat gewenst is vanuit het perspectief van de gevestigde organisaties, onwenselijk kan zijn vanuit het perspectief van de maatschappij. Toch is het ook hier niet zo eenvoudig als op het eerste gezicht lijkt. Von Weizsäcker (1980) laat bijvoorbeeld zien dat bepaalde toetredingsbelemmeringen - en dus bepaalde bedrijfstakinerties - de maatschappelijke welvaart kunnen verhogen. 
experimenten in de vorm van het gevangenendilemma, zoals in paragraaf 4 beschreven, hebben zij onderzocht welke invloed de culturele samenstelling van taakgroepen heeft op het functioneren van deze groepen in termen van concurrentie en samenwerking. Hierbij is rekening gehouden met vier verschillende etnische groeperingen uit de Amerikaanse samenleving: Angelsaksische, Aziatische, Latijnse en Afrikaanse Amerikanen. De cruciale bevinding is dat taakgroepen met louter Angelsaksische leden aanmerkelijk minder samenwerking ten toon spreiden dan taakgroepen met nietAngelsaksische leden. Ook hier blijkt weer dat heterogeniteit de effectiviteit van een (taak)groep bevordert. Met andere woorden: samenwerking binnen taakgroepen - alles behalve een onbekende werkvorm binnen organisaties: in welke organisatie is het niet belangrijk om samen te werken? - heeft een grotere kans van slagen in multicultureel samengestelde eenheden! Het antwoord op de hiervoor gestelde vraag is dus "ja": het helpt organisaties om cultureel tolerant te zijn.

\section{Dankbetuiging}

Mijn loopbaan kent een alles behalve lineair verloop. Het toeval heeft een grote rol gespeeld. Dat toeval is door een aantal mensen gestuurd. Een drietal wil ik hier niet onvermeld laten. Professor Simon Kuipers - nog even rector magnificus van en straks weer hoogleraar macroeconomie aan de Rijksuniversiteit Groningen - heeft mij op het wetenschappelijke pad gestuurd. Zonder Professor Hans Maks - toen werkzaam in Groningen en nu hoogleraar micro-economie in Maastricht - zou ik vermoedelijk macro-econoom zijn gebleven. Professor Hein Schreuder - indertijd mijn voorganger (maar dat wisten we toen nog niet) en inmiddels DSM-strateeg - heeft om voor mij nog altijd raadselachtige redenen mijn overstap naar de bedrijfseconomie geregeld. Zonder de bijsturing van deze drie zeer gewaardeerde vakgenoten was ik nu vermoedelijk zoiets geweest als een kleurloze ambtenaar in Den Haag of Lutjebroek.

Maar het moet gezegd: ik ben met mijn neus in de boter gevallen. De Maastrichtse Economische Faculteit is een bijzonder aangename en stimulerende werkomgeving (en Limburg een aangename woonomgeving!). Hetzelfde geldt zeker ook voor mijn collega's binnen de sectie organisatie. Het is dan ook geen wonder dat veel van mijn onderwijsprodukten en onderzoekpublicaties tot stand zijn gekomen in samen- 
werking met Maastrichtse vakgenoten. Ik hoop en verwacht dat deze vruchtbare samenwerking in de toekomst kan worden voortgezet.

Tot slot mijn familie. Met mijn broers kan ik altijd van gedachten wisselen over zulke belangwekkende en boeiende onderwerpen als het horecawezen in Arnhem en de baute cuisine in Moskou. In ieder geval delen wij onze liefde voor popmuziek. Als het maar hard is, zoals Nirvana! Alle wrange grappen over de schoonfamilie zijn op mij niet van toepassing. Mijn ouders hebben mij in de gelegenheid gesteld mijn talenten - voorzover aanwezig - ten volle te ontplooien. Mijn woning financieren en mijn kleren wassen doen ze niet meer, maar ze staan nog altijd klaar om ten minste morele steun te verlenen. En dan Banholt: daar kan ik elke dag weer genieten van twee schatten van dochters, die het mij mogelijk maken de veertig uren werktijd op volle kracht door te komen. Maar vooral: Hettie. Zonder haar was ik hooguit die kleurloze ambtenaar in Lutjebroek geworden.

Ik beb gezegd. ${ }^{30}$

No Limits! (Two Unlimited, 1993)

N'ssi N'ssi (Chaled, 1993)

30 Deze oratie is - bij wijze van experiment - geschreven zonder gebruikmaking van het afzonderlijke woord 'er' (met uitzondering van deze noot natuurlijk). Is $u$ dat opgevallen? Heeft $u$ het woord gemist? En wat vindt $u$ ervan? 


\section{Literatuurlijst}

Abell, D.F. - Defining the Business: The Starting Point of Strategic Planning, 1980, Englewood Cliffs, NJ: Prentice-Hall.

Akerlof, G.A. - "Procrastination and Obedience", 1991, American Economic Review: Papers and Proceedings, 81, 1-19.

Alchian, A. \& H. Demsetz - "Production, Information Costs, and Economic Organization", 1972, American Economic Review, 62, 777-795.

Alessie, R. \& A. Kapteyn - "Habit Formation, Interdependent Preferences and Demographic Effects in the Almost Ideal Demand System', 1991, Economic Joumal, 101, 404-419.

Arrow, K.J. - "Uncertainty and Medical Care", 1963, American Economic Review, 53, 941-973.

Barnard, C.I. - The Functions of the Executive, 1938, Cambridge, MA: Harvard Business Press.

Baum, J.A.C. \& S.J. Mezias - "Localized Competition and Organizational Failure in Manhattan Hotel Industry: 1898-1990", 1991, Administrative Science Quarterly, 37, 580-604.

Baumol, W.J. - Business Bebaviour, Value and Growth, 1963, New York: McMillan.

Bertrand, J. - "Théorie mathématique de la richesse sociale", 1883, Journal des savants, 499-508.

Boone, C. \& B. de Brabander - "Generalized versus Specific Locus of Control Expectancies of Chief Executive Officers", 1993 , Strategic Management Journal, 14, 619-626.

Boone, C., B. de Brabander \& A. van Witteloostuijn - "Het verband tussen de samenstelling van het topmanagementteam enerzijds en het adaptievermogen van organisaties anderzijds: een contingentiebenadering", 1993, Onderzoekmemorandum RM-049, Maastricht: Rijksuniversiteit Limburg.

Boone, C., B. de Brabander \& A. van Witteloostuijn - "The Effects of Individual Differences on Competitive and Cooperative Choices in Five Prisoner's Dilemma Games", 1994, Research Memorandum, Maastricht: Rijksuniversiteit Limburg.

Boone C. \& A. van Witteloostuijn - "Hypercompetitive Rivalry: Flexibility, Inertia and Performance", 1994, Research Memorandum, Maastricht: Rijksuniversiteit Limburg.

Boone, C. \& A. van Witteloostuijn - "Industrial Organization and Organizational Ecology: The Potentials for Cross-fertilization", 1995, Organization Studies, 15, in druk.

Buijink, W., A. van Witteloostuijn, S. Maijoor \& M. Zinken - The Evolution of the Structure of the Dutcb Audit Industry: An Explanatory Empirical Study, 1994, Amsterdam: Limperg Instituut.

Burns, T. \& G.M. Stalker - The Management of Innovation, 1961, Londen: Tavistock. 
Coase, R.H. - "The Nature of the Firm", 1937, Economica, 4, 386-405.

Cournot, A. - Researches into the Mathematical Principles of the Theory of Wealth, 1897, New York: McMillan (eerste Franstalige druk: 1838).

Cox, T.H., S.A. Lobel \& P.L. McLeod - "Effects of Ethnic Group Cultural Differences on Cooperative and Competitive Behavior on a Group Task", 1991, Academy of Management Journal, 34, 827-847.

Cyert, R.M. \& J.G. March - A Bebavioral Theory of the Firm, 1963, Englewood Cliffs, NJ: Prentice-Hall.

Daft, R.L. - Organization Theory and Design, 1992, Saint Paul: West Publishing Company.

Dietz, J.L.G. - Zo gezegd, zo gedaan, 1990, Oratie, Schoonhoven: Academic Service.

Dixit, A. - "Entry and Exit Decisions under Uncertainty", 1989, Journal of Political Economy, 97, 620-638.

Dixit, A. - "Investment and Hysteresis", 1992, Journal of Economic Perspectives, 6, 107-132.

Douma, S. \& H. Schreuder - Economic Approaches to Organizations, 1991, New York: Prentice-Hall.

Finkelstein, S. \& D.C. Hambrick - "Top-Management-Team Tenure and Organizational Outcomes: The Moderating Role of Managerial Discretion", 1990, Administrative Science Quarterly, 35, 484-503.

Fisher, F.M. - "Games Economists Play: A Noncooperative View", 1986, RAND Joumal of Economics, 20, 113-137.

Ghemawat, P. - Commitment: The Dynamic of Strategy, 1991, New York: Free Press.

Gollier, C. - "Wage Differentials, the Insider-Outsider Dilemma, and Entry Deterrence", 1991, Oxford Economic Papers, 43, 391-408.

Gordon, G.G. - "Industry Determinants of Organizational Culture", 1991, Academy of Management Review, 16, 396-415.

Grether, D.M. - "Testing Bayes Rule and the Representativeness Heuristic: Some Experimental Evidencen, 1992, Joumal of Economic Behavior and Organization, 17, 31-58.

Hagedoorn, J. - International Business: Complexity, Flexibility and the Role for Forecasting, 1993, Oratie, Maastricht: Universitaire Pers Maastricht.

Hambrick, D.C. \& R.A. D'Aveni - "Large Corporate Failures as Downward Spirals", 1988, Administrative Science Quarterly, 33, 1-23.

Hannan, M.T. \& G.R. Carroll - Dynamics of Organizational Populations: Density, Legitimation, and Competition, 1992, Oxford: Oxford University Press.

Hannan, M.T. \& J. Freeman - "The Population Ecology of Organizations", 1977, American Journal of Sociology, 82, 929-964.

Hannan, M.T. \& J. Freeman - "Structural Inertia and Organizational Change", 1984, American Sociological Review, 49, 149-164.

Hannan, M.T. \& J. Freeman - Organizational Ecology, 1989, Cambridge, MA: Harvand University Press.

Hofstede, G.H. - Cultures and Organizations: Software of the Mind, 1991, 
Londen: McGraw-Hill.

Holmstrom, B.R. \& J. Tirole - "The Theory of the Firm", 1989, in: Schmalensee, R.D. \& R. Willig (red.) - Handbook of Industrial Organization, Amsterdam: North-Holland, 61-134.

Janis, I.L. - "Groupthink", 1971, Psychology Today, herdrukt in: Hackman, J.R., E.E. Lawler III \& L.W. Porter (red.) - Perspectives on Behavior in Organizations, 1983, New York: McGraw-Hill, 378-384.

Jensen, M.C. \& W. Meckling - "Theory of the Firm: Managerial Behavior, Agency Costs and Ownership Structure", 1976, Joumal of Financial Economics, 3, 305-360.

Jensen, M.C. \& K.J. Murphy - "Performance Pay and Top Management Incentives", 1990, Journal of Political Economy, 98, 225-264.

Johnson, G. \& K. Scholes - Exploring Corporate Strategy: Text and Cases, 1993, New York: Prentice-Hall.

Kasper, J.D.P. - Marktgerichte marketing: taalkundig slordigbeidje of bittere noodzaak?, 1990, Oratie, Deventer: Kluwer.

Keizer, P. \& J. Soeters (red.) - Economie, sociologie en psychologie: visies op integratie, 1987, Assen/Maastricht: Van Gorcum.

Lammers, C.J. - Organiseren van bovenaf en van onderop: een beknopte inleiding in de organisatiesociologie, 1993, Utrecht: Het Spectrum.

Lawrence, P.R. \& J.W. Lorsch - Organization and Environment, 1967, Cambridge, MA: Harvard University Press.

Lea, S.E.G., R.M. Tarpy \& P. Webley - The Individual in the Economy: $A$ Survey of Economic Psychology, 1987, Cambridge: Cambridge University Press.

Lier, A. van \& A. van Witteloostuijn - "Big is Beautiful: Cournot Competition, Habit Formation, and Exit", 1993, Research Memorandum RM 93-016, Maastricht: Rijksuniversiteit Limburg.

Maijoor, S. \& A. van Witteloostuijn - "An Empirical Test of the ResourceBased Theory of Competitive Advantage: Strategic Regulation and Stratified Promotion in the Dutch Audit Industry", 1993, Research Memorandum MARC-RM-1993/017, Maastricht: Rijksuniversiteit Limburg. Maijoor, S., W. Buijink, A. van Witteloostuijn \& M. Zinken - "Long-Term Concentration in the Dutch Audit Market: The Use of Auditor Association Membership Lists in Historical Research", 1993, Research Memorandum MARC-RM-1993/019, Maastricht: Rijksuniversiteit Limburg.

Malthus, T.R. - An Essay on Population, 1798, Londen: Johnson.

Marris, R. - Theory of "Managerial" Capitalism, 1964, Londen: McMillan.

Marshall, A. - Principles of Economics (achtste editie), 1920, Londen: McMillan.

Meyer, M.W. \& L.G. Zucker - Permanently Failing Organizations, 1989, Newbury Park, CA: Sage.

Miles, R.E. \& C.C. Snow - "Fit, Failure and the Hall of Fame", 1984, California Management Review, 26, 10-28.

Milgrom, P. \& J. Roberts - Economics, Organization and Management, 1992, Englewood Cliffs, NJ: Prentice-Hall. 
Miller, D. \& J.M. Toulouse - "Strategy, Structure, CEO Personality and Performance in Small Firms", 1986, American Joumal of Small Business, 10, 47-62.

Mintzberg, H. - "The Five Ps for Strategy", 1987, Califormia Management Review, herdrukt in: Mintzberg, H. \& J.B. Quinn (red.) - The Strategy Process: Concepts, Contexts, Cases, 1991, Englewood Cliffs, NJ: PrenticeHall, 12-19.

Morgan, G. - Images of Organizations, 1986, Beverly Hills, CA: Sage.

Pennings, J.M. - "Naar een comparatieve dynamica", 1993, in: Doorn, J. van, P. Meurs \& T. Mijs (red.) - Het organisatorisch labyrint: een vriendenboek voor Cor Lammers bij zijn afscheid als boogleraar, Utrecht: Het Spectrum, 234-248.

Pfeffer, J. - Organizations and Organization Theory, 1982, Cambridge, MA: Ballinger Publishing.

Pfeffer, J. - "Barriers to the Advance of Organizational Science: Paradigm Development as a Dependent Variable", 1993, Academy of Management Review, 18, 599-620.

Pfeffer, J. \& G.R. Salancik - "The Design and Management of Externally Controlled Organizations", 1978, herdrukt in: Pugh, D.S. (red.) - Organization Theory: Selected Readings, 1990, 146-177.

Plott, C.R. - "An Updated Review of Industrial Organization: Applications of Experimental Methods", 1989, in: Schmalensee, R.D. \& R. Willig (red.) - Handbook of Industrial Organization, Amsterdam: North-Holland, 11091178.

Poel, J.H.R. van de - Als de tekenen bedriegen ..., 1988, Oratie, Groningen: Wolters-Noordhoff.

Poitevin, M. - "Financial Signalling and the 'Deep-Pocket' Argument", 1989, RAND Journal of Economics, 20, 26-40.

Porter, M.E. - "Please Note Location of Nearest Exit: Exit Barriers and Planning", 1976, California Management Review, 19, 21-33.

Porter, M.E. - Competitive Strategy: Techniques for Analyzing Industries and Competitors, 1980, New York: Free Press.

Porter, M.E. - Competitive Advantage: Creating and Sustaining Superior Performance, 1985, New York: Free Press.

Pruitr, D. \& M. Kimmel - "Twenty Years of Experimental Gaming: Critique, Synthesis, and Suggestions for the Future", 1977, Annual Review of Psychology, 28, 363-392.

Quinn, J.B. - "Logical Incrementalism", 1978, Sloan Management Review, herdrukt in: Mintzberg, H. \& J.B. Quinn (red.) - The Strategy Process: Concepts, Contexts, Cases, 1991, Englewood Cliffs, NJ: Prentice-Hall, 96104.

Quinn, J.B. - Strategies for Change: Logical Incrementalism, 1980, Homewood, IL: Irwin.

Robbins, S.P. - Organizational Behavior, 1993, Englewood Cliffs, NJ: Prentice-Hall.

Rotter, J.B. - "Generalized Expectancies for Internal versus External Control 
of Reinforcement", 1966, Psychological Monographs: General and Applied, 80, Whole No. 609.

Rotter, J.B. - "Some Problems and Misconceptions Related to the Construct of Internal versus External Control of Reinforcement", 1975, Joumal of Consulting and Clinical Psychology, 43, 56-67.

Sah, R.K. \& J.E. Stiglitz - "Committees, Hierarchies and Polyarchies", 1988, Economic Journal, 98, 451-470.

Schelling, T.C. - The Strategy of Conflict, 1960, Cambridge, MA: Harvard University Press.

Scherer, F.M. \& D. Ross - Industrial Market Structure and Economic Perfor. mance, 1990, Boston: Houghton Mifflin.

Schmalensee, R. \& R.D. Willig (red.) - Handbook of Industrial Organization, 1989, Amsterdam: North-Holland.

Schreuder, H. - Economie (en) bedrijuen, 1985, Oratie, Assen/Maastricht: Van Gorcum.

Schumpeter, J.A. - Capitalism, Socialism and Democracy, 1943, Londen: George Allen and Unwin.

Schumpeter, J.A. - History of Economic Analysis, 1954, New York: Oxford University Press.

Shapiro, C. - "The Theory of Business Strategy", 1989, RAND Joumal of Economics, 20, 125-137.

Smith, A. - The Wealth of Nations: Books I-III, 1979, Harmondsworth: Penguin (eerste druk: 1776).

Soete, L.L.G. - Technologie en economie, 1987, Oratie, Maastricht: Faculteit der Economische Wetenschappen.

Spencer, B.J. \& J.A. Brander - "Pre-Commitment and Flexibility: Applications to Oligopoly Theory", 1992, European Economic Review, 36, 16011626.

Stacey, R.D. - Strategic Management and Organisational Dymamics, 1993, Londen: Pitman Publishing.

Stigler, G.J. (red.) - Business Concentration and Price Policy, 1955, Princeton: Princeton University Press.

Sutton, J. - Sunk Costs and Market Structure: Price Competition, Advertising, and the Evolution of Concentration, 1991, Cambridge, MA: MTT Press.

Taylor, F.W. - Scientific Management, 1911, New York: Harper.

Tirole, J. - The Theory of Industrial Organization, 1988, Cambridge, MA: MTT Press.

Vendrik, M.C.M. - "Habits, Hysteresis and Catastrophies in Labor Supply', 1993, Journal of Economic Behavior and Organization, 20, 353-372.

Vickers, J. - "Delegation and the Theory of the Firm", 1985, Economic Journal, 95, 138-147.

Walras, L. - Eléments d'économie politique pure, 1874, Lausanne: Corbaz en Elements of Pure Economics, 1954, Homewood, IL: Irwin.

Wegberg, M. van \& A. van Witteloostuijn - "Credible Entry Threats into Contestable Markets: A Symmetric Multimarket Model of Contestability', 1992, Economica, 59, 437-452. 
Weizsäcker, C.C. von - "A Welfare Analysis of Barriers to Entry", 1980, Bell Journal of Economics, 11, 399-420.

Williamson, O.E. - The Economics of Discretionary Behavior, 1964, Englewood Cliffs, NJ: Prentice-Hall.

Williamson, O.E. - "Transaction Cost Economics", 1989, in: Schmalensee, R.D. \& R. Willig (red.) - Handbook of Industrial Organization, Amsterdam: North-Holland, 135-182.

Witteloostuijn, A. van - "Maximising and Satisficing: Opposite or Equivalent Concepts?", 1988, Joumal of Economic Psychology, 9, 289-313.

Witteloostuijn, A. van - "Economic Psychology and Socio-Economics: An Essay on Discourse Strategies and Research Potentials", 1992, in: Antonides, G., W. Arts \& W.F. van Raaij (red.) - The Consumption of Time and the Timing of Consumption: Toward a New Bebavioral and Socio. Economics, Amsterdam: North-Holland, 232-242.

Witteloostuijn, A. van - "Multimarket Competition and Business Strategy", 1993, Review of Industrial Organization, 8, 83-99.

Witteloostuijn, A. van \& J.A.H. Maks - "Walras: A Hicksian 'avant la lettre'", 1989, Economie appliquéee, 41, 595-608.

Witteloostuijn, A. van \& J.A.H. Maks - "Walras on Temporary Equilibrium and Dynamics", 1990, History of Political Economy, 22, 223-237.

Witteloostuijn, A. van \& M. van Wegberg - "Multimarket Competition: Theory and Evidence", 1992, Journal of Economic Behavior and Organizati. on, 18, 273-282.

Wolf, C.C.P. - Pensioenverzekering? Een financieel-economische beschouwing, 1989, Oratie, Assen/Maastricht: Van Gorcum.

Woodward, J. - Industrial Organization: Theory and Practice, 1965, Oxford: Oxford University Press.

Zajac, E.J. \& M.H. Bazerman - "Blind Spots in Industry and Competitor Analysis: Implications of Interfirm (Mis)perceptions for Strategic Decisions", 1991, Academy of Management Review, 16, 37-56. 